Review

\title{
Changes in Subcellular Localization of Host Proteins Induced by Plant Viruses
}

\author{
Rosalba Rodriguez-Peña ${ }^{1}$, Kaoutar El Mounadi ${ }^{2}$ (I) and Hernan Garcia-Ruiz ${ }^{1, *(1)}$ \\ 1 Department of Plant Pathology, Nebraska Center for Virology, University of Nebraska-Lincoln, \\ Lincoln, NE 68503, USA; rrodriguezpena2@unl.edu \\ 2 Department of Biology, Kutztown University of Pennsylvania, Kutztown, PA 19530, USA; \\ elmounadi@kutztown.edu \\ * Correspondence: hgarciaruiz2@unl.edu; Tel.: +1-4-02-472-3008
}

Citation: Rodriguez-Peña, R.;

Mounadi, K.E.; Garcia-Ruiz, H.

Changes in Subcellular Localization of Host Proteins Induced by Plant

Viruses. Viruses 2021, 13, 677.

https://doi.org/10.3390/v13040677

Academic Editors: Eugene Savenkov and Katalin Nemes

Received: 18 March 2021

Accepted: 12 April 2021

Published: 15 April 2021

Publisher's Note: MDPI stays neutral with regard to jurisdictional claims in published maps and institutional affiliations.

Copyright: (C) 2021 by the authors. Licensee MDPI, Basel, Switzerland. This article is an open access article distributed under the terms and conditions of the Creative Commons Attribution (CC BY) license (https:// creativecommons.org/licenses/by/ $4.0 /)$.

\begin{abstract}
Viruses are dependent on host factors at all parts of the infection cycle, such as translation, genome replication, encapsidation, and cell-to-cell and systemic movement. RNA viruses replicate their genome in compartments associated with the endoplasmic reticulum, chloroplasts, and mitochondria or peroxisome membranes. In contrast, DNA viruses replicate in the nucleus. Viral infection causes changes in plant gene expression and in the subcellular localization of some host proteins. These changes may support or inhibit virus accumulation and spread. Here, we review host proteins that change their subcellular localization in the presence of a plant virus. The most frequent change is the movement of host cytoplasmic proteins into the sites of virus replication through interactions with viral proteins, and the protein contributes to essential viral processes. In contrast, only a small number of studies document changes in the subcellular localization of proteins with antiviral activity. Understanding the changes in the subcellular localization of host proteins during plant virus infection provides novel insights into the mechanisms of plant-virus interactions and may help the identification of targets for designing genetic resistance to plant viruses.
\end{abstract}

Keywords: antiviral; colocalization; host factors; protein relocalization; proviral; replication proteins; TuMV

\section{Introduction}

The most abundant plant viruses have a genome that is a positive single-strand RNA (Group IV) or a negative single-strand RNA (Group V). Single-strand RNA viruses replicate in compartments or vesicles bound to membranes in the cytoplasm or in subcellular organelles [1]. Plant-infecting DNA viruses, on the other hand, are less numerous. Singlestrand DNA (Group II) and reverse-transcribing DNA (Group VII) viruses replicate by forming a minichromosome in the nucleus [2].

Viral RNA is translated into proteins using the cellular machinery. Viral nucleic acids and proteins execute their functions in cooperation with host proteins, RNAs, or other factors such as membranes or lipids [3,4]. These components condition susceptibility, and their absence reduces virus accumulation or movement, and may turn a host into a nonhost. These factors encode loss-of-susceptibility genes, also named susceptibility genes $[3,5]$. Because the presence and activity of these host components are essential for the virus, the terms cellular factors with proviral activity or proviral host factors are often used in publications $[3,6]$.

The establishment of a viral infection is genetically determined at two sequential phases. Initially, the absence of susceptibility genes results in the lack of infection or reduced virus replication and/or movement [3]. When a plant has the susceptibility genes needed for the initiation of infection, in a second phase, virus accumulation, spread, and disease severity are determined by the balance between plant defense and viral suppression of defense responses [7]. 
Viral infection induces changes in host gene expression [8,9] resulting in the upregulation of susceptibility genes [10] and activation or downregulation of antiviral defense responses [11,12], and may also lead to up- or downregulation of genes that have no effect on the virus $[8,9]$. Upregulation of antiviral genes indicates the activation of defense responses by multiple mechanisms including autophagy, RNA decay, or gene silencing $[7,13,14]$. Antiviral defense is mediated by host factors that target viral proteins or nucleic acids and antagonize key parts of virus replication and/or movement, reducing virus accumulation or limiting the spread of infection within the plant $[7,15]$. However, to protect themselves, viruses may downregulate expression, suppress activity, or induce degradation of antiviral defense components [16]. The molecular mechanisms and significance of changes in host gene expression during viral infection are still poorly understood.

Viruses divert host proteins from their natural roles to execute essential viral processes such as translation, virus replication, or movement $[5,17,18]$. Changes in activity are often associated with a change in the subcellular localization of the host protein. A protein is considered to relocalize when, in the presence of a virus, a fraction of the total protein accumulates in a new place in the cell. These changes have been detected and characterized by a combination of approaches such as yeast two hybrid, subcellular fractionation, bimolecular fluorescence complementation, immunofluorescence confocal microscopy, or co-precipitation [19-21].

In this review, we present an analysis of publications documenting changes in the subcellular localization of host proteins following viral infection. Results present a profile of the host proteins that change, the experimental approaches used to identify them, their natural and new locations, and their role in favor or against viruses. The profiles advance our understanding of the mechanisms that govern plant-virus interactions and establish the basis for the identification of novel host factors with antiviral activity or that condition virus susceptibility and that can be targeted to generate virus-resistant plants by genetic engineering.

\section{Profile of Host Proteins}

Plant viruses for which at least one host protein has been reported to change subcellular localization were grouped based on their genome organization. The site of genome replication, name of the replication protein, and movement form were compiled and used as a guide to interpret interaction with and recruitment of host proteins (Table 1). We classified the host proteins based on their natural subcellular localization in the absence of viral infection. Changes in subcellular localization were documented for 55 combinations of host protein and plant virus. After profiling features of these proteins and viruses, several general patterns emerged: (1) 45 of the 55 combinations were identified using model hosts (Arabidopsis thaliana, Nicotiana benthamiana, or Saccharomyces cerevisiae, Figure 1A); (2) the majority (48) were identified using model positive-strand RNA viruses (Figure 1C), particularly brome mosaic virus (BMV), tomato bushy stunt virus (TBSV), and turnip mosaic virus (TuMV) (Figure 1D); (3) in 46 of the 55 combinations, the host protein is beneficial to the virus; (4) host proteins with antiviral roles were less abundant (nine) (Figure 1B); and (5) the most frequent group (30 out of 55) was host proteins that moved from the cytoplasm to the sites of virus replication (Figure 2A and Table 2) through interactions with viral proteins (Table 2). These patterns are heavily influenced by the combination of experimental hosts and viruses used as model systems. 
Table 1. Site of replication and movement form of plant viruses for which at least one host protein has been reported to change subcellular localization.

\begin{tabular}{|c|c|c|c|c|c|}
\hline Virus & $\operatorname{RdRp}$ & Site of Replication & $\begin{array}{l}\text { Intracellular Movement of the } \\
\text { Replication Compartments }\end{array}$ & $\begin{array}{c}\text { Cell-To-Cell } \\
\text { Movement Form }\end{array}$ & Reference \\
\hline \multicolumn{6}{|c|}{ Group II: Single-strand DNA } \\
\hline TYLCV & Rep protein & Nucleus & From nucleus to plasmodesmata & Minichromosome & {$[22]$} \\
\hline \multicolumn{6}{|c|}{ Group IV: Single positive-strand RNA } \\
\hline BaMV & $155 \mathrm{kDa}$ & Chloroplast & $\begin{array}{l}\text { From chloroplast to } \\
\text { plasmodesmata }\end{array}$ & $\begin{array}{c}\text { Virions or } \\
\text { ribonucleoprotein } \\
\text { particles }\end{array}$ & {$[23]$} \\
\hline BMV & $2 \mathrm{a}$ & Endoplasmic reticulum & Non-motile & $\begin{array}{c}\text { Virions or } \\
\text { ribonucleoprotein } \\
\text { particles }\end{array}$ & {$[24]$} \\
\hline CIRV & p36 & Mitochondria & Non-motile & $\begin{array}{l}\text { Ribonucleoprotein } \\
\text { particles }\end{array}$ & {$[25]$} \\
\hline $\mathrm{CNV}$ & p33 & Peroxisome & Non-motile & $\begin{array}{l}\text { Ribonucleoprotein } \\
\text { particles }\end{array}$ & {$[26]$} \\
\hline GRV & $\operatorname{RdRp}$ & Cytoplasm & NA & $\begin{array}{l}\text { Ribonucleoprotein } \\
\text { particles }\end{array}$ & {$[27]$} \\
\hline LMV & $\mathrm{NIb}$ & Endoplasmic reticulum & From ER to plasmodesmata & Replication vesicles & [28] \\
\hline PepMV & $164 \mathrm{kDa}$ & $\begin{array}{c}\text { Cytoplasm } \\
\text { (membrane association } \\
\text { with ER is unclear) }\end{array}$ & From cytoplasm to plasmodesmata & $\begin{array}{l}\text { Ribonucleoprotein } \\
\text { particles }\end{array}$ & {$[29]$} \\
\hline PVX & $\operatorname{RdRp}$ & Endoplasmic reticulum & NA & $\begin{array}{l}\text { Virions or } \\
\text { ribonucleoprotein } \\
\text { particles }\end{array}$ & {$[30]$} \\
\hline RCNMV & p27 and p88 & Endoplasmic reticulum & From ER to plasmodesmata & Virions & {$[31-33]$} \\
\hline TVCV & $\operatorname{RdRp}$ & Endoplasmic reticulum & From ER to plasmodesmata & $\begin{array}{l}\text { Virions or } \\
\text { ribonucleoprotein } \\
\text { particles }\end{array}$ & {$[34]$} \\
\hline TBSV & p92pol & Peroxisomes & Non-motile & $\begin{array}{c}\text { Ribonucleoprotein } \\
\text { particles }\end{array}$ & {$[35,36]$} \\
\hline TMV & $\operatorname{RdRp}$ & Endoplasmic reticulum & From ER to plasmodesmata & $\begin{array}{l}\text { Replication complexes or } \\
\text { ribonucleoprotein } \\
\text { particles }\end{array}$ & {$[37]$} \\
\hline ToMV & $130 \mathrm{~K}$ and $180 \mathrm{~K}$ & Endoplasmic reticulum & From ER to plasmodesmata & $\begin{array}{c}\text { Virions or } \\
\text { ribonucleoprotein } \\
\text { particles }\end{array}$ & {$[38]$} \\
\hline TuMV & $\mathrm{NIb}$ & ER and chloroplasts & $\begin{array}{c}\text { From ER to chloroplast and/or to } \\
\text { Golgi apparatus and to } \\
\text { plasmodesmata }\end{array}$ & Replication vesicles & {$[28]$} \\
\hline TVBMV & $\mathrm{NIb}$ & Chloroplasts & $\begin{array}{c}\text { From ER to chloroplast and/or to } \\
\text { Golgi apparatus and to } \\
\text { plasmodesmata }\end{array}$ & Replication vesicles & {$[39,40]$} \\
\hline \multicolumn{6}{|c|}{ Group V: Single negative-strand RNA } \\
\hline RSV & $337 \mathrm{kDa}$ & $\begin{array}{l}\text { Cytoplasm } \\
\text { (membrane association } \\
\text { is unknown) }\end{array}$ & $\begin{array}{l}\text { From ER to Golgi to } \\
\text { plasmodesmata }\end{array}$ & Virion-protein complexes & {$[41-43]$} \\
\hline \multicolumn{6}{|c|}{ Group VII: Double-strand DNA-RT } \\
\hline CaMV & Rep protein & Nucleus & $\begin{array}{l}\text { From nucleus to ER and/or } \\
\text { directly to plasmodesmata }\end{array}$ & Virions & {$[44]$} \\
\hline
\end{tabular}

Viruses: bamboo mosaic virus (BaMV), brome mosaic virus (BMV), cauliflower mosaic virus (CaMV), carnation Italian ringspot virus (CIRV), cucumber necrosis virus (CNV), groundnut rosette virus (GRV), lettuce mosaic virus (LMV), pepino mosaic virus (PepMV), potato virus X (PVX), red clover necrotic mosaic virus (RCNMV), rice stripe virus (RSV), turnip vein-clearing virus (TVCV), tobacco mosaic virus (TMV), tomato bushy stunt virus (TBSV), tomato mosaic virus (ToMV), turnip mosaic virus (TuMV), tobacco vein banding mosaic virus (TVBMV), tomato yellow leaf curl virus (TYLCV). Viral proteins. NIb: nuclear inclusion protein b, the RNA-dependent RNA polymerase in potyviruses; RdRp: RNA-dependent RNA polymerase; NA: information not available; ER: endoplasmic reticulum. 
A Hosts

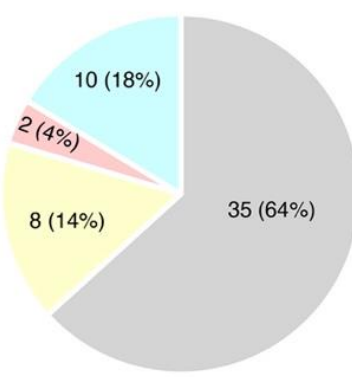

N. benthamiana

S. cerevisiae

A. thaliana

Others
B Roles

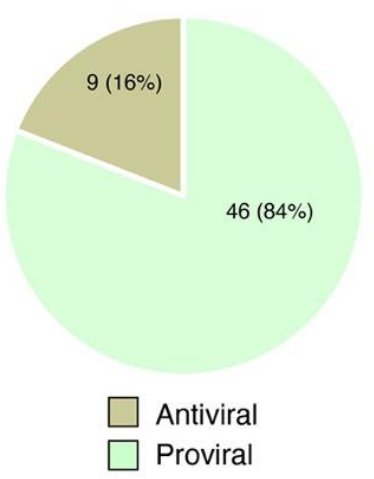

C Virus group

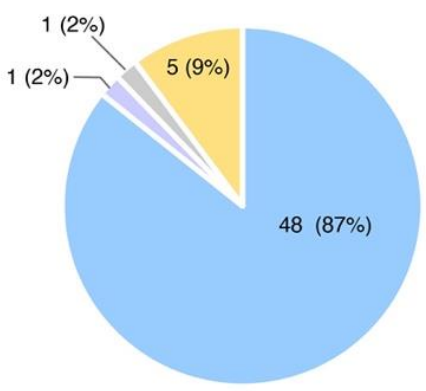

(+) SsRNA

(-) SSRNA

ssDNA

dsDNA-RT

D Viruses

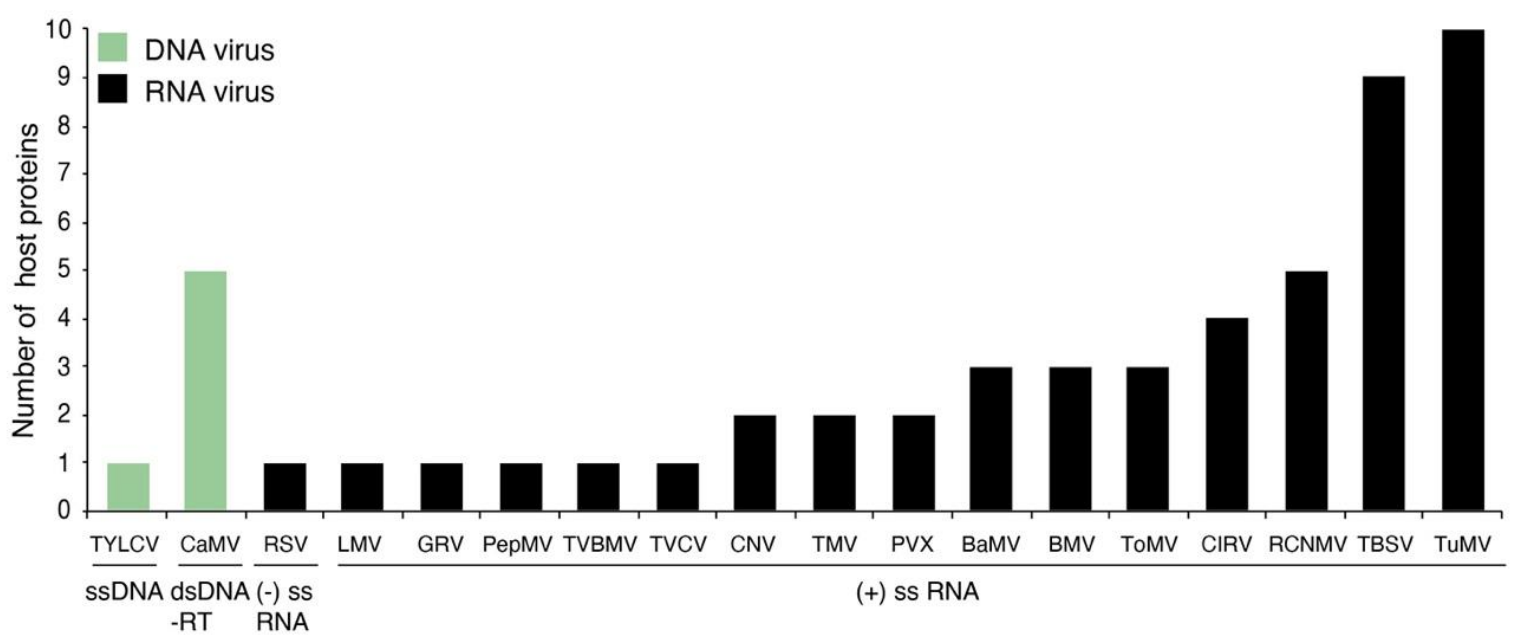

Figure 1. Profile of host proteins that change their subcellular localization during plant virus infection as reported in the literature. Fifty-five combinations of host protein-plant virus were documented in publications. (A) Number and proportion of proteins by host species. (B) Number and proportion of host proteins with antiviral role or beneficial to the virus. (C) Number and proportion of host proteins by virus group. (D) Number of host proteins by virus species. Viruses are grouped based on their genome organization.

\section{Cytoplasmic Host Proteins}

Of the 55 host proteins that changed their localization during viral infection, 30 were cytoplasmic and moved to the sites of virus replication in the mitochondria, chloroplasts, endoplasmic reticulum (ER), peroxisomes, or nucleus and participated in essential processes such as the formation of the sites of virus replication, stimulation of RNA synthesis, or stability of the RNA-dependent RNA polymerase (Figure 2 and Table 2). Host proteins represented include heat shock proteins, translation factors, and proteins that mediate membrane topology (Table 2). Other proteins include GSTU4 (glutathione transferases), oxysterol-binding protein-related proteins (ORPs), catalase 1, endosomal sorting complexes required for transport (ESCRTs), and like Sm protein 1 (LSm1). Two antiviral proteins (NPR1 and 20S $\alpha 5$ ) moved from the cytoplasm to the nucleus or virus-induced aggregates. Their new localization was mediated by viral proteins and resulted in the loss of antiviral activity (Table 3). Cytoplasmic proteins with a new distribution in virus-infected cells are discussed below. 


\section{A Cytoplasmic host proteins}
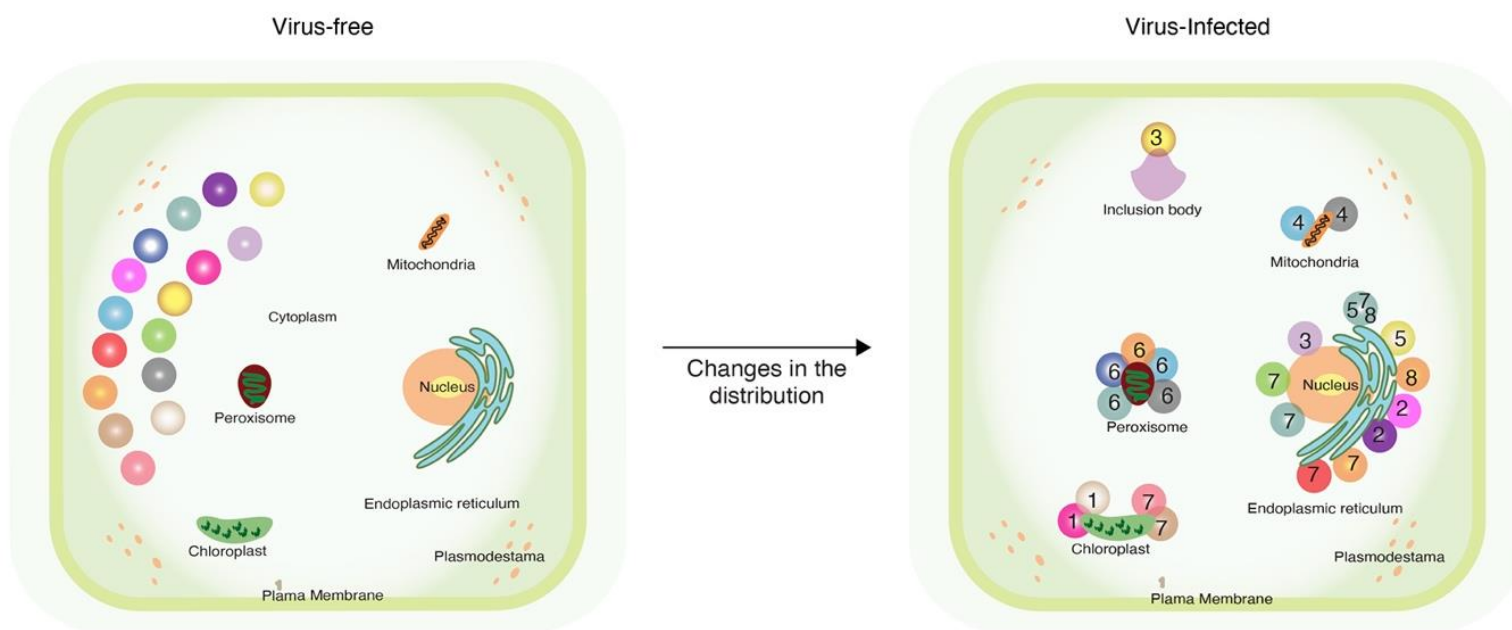

Host proteins

\begin{tabular}{|c|c|c|}
\hline AtRH8 & AtRH9 & eEF1A $\bigcirc$ elF(iso) $4 \mathrm{e}$ \\
\hline HSP70 & HSP90 & CLM1 \\
\hline RICP & GAPDH & ESCRT-III \\
\hline PABP2 & PR1 & RACK1 \\
\hline
\end{tabular}

Viruses

$\begin{array}{llll}\text { 1. BaMV 2. BMV 3. CaMV 4. CIRV } & \text { 2. }\end{array}$

5. RCNMV 6. TBSV 7. TUMV 8. TOMV

\section{B Organelle proteins}
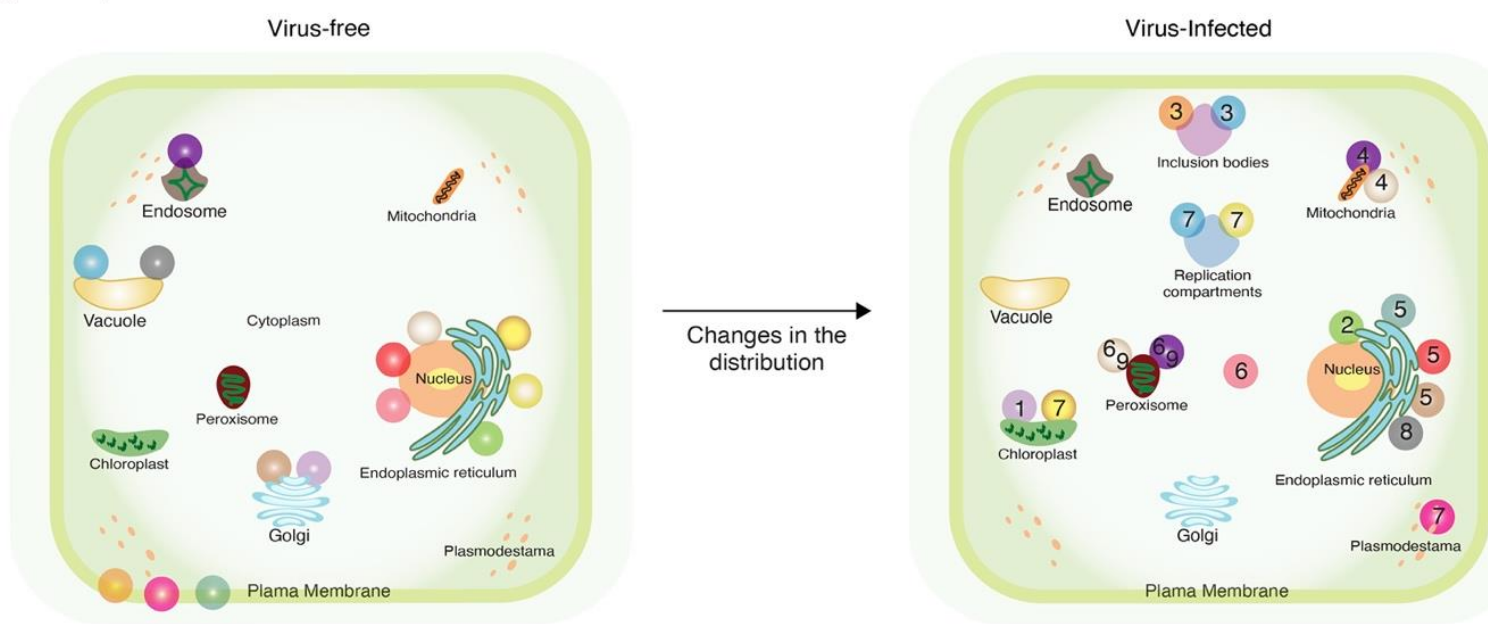

Host proteins

\begin{tabular}{|c|c|c|c|}
\hline ALY & ARF1 & (1) ATSRC & 0 \\
\hline $\mathrm{RBOHB}$ & PCaP1 & - RAB5 & $\mathrm{RH} 30$ \\
\hline SYP71 & том & NBR1 & RHP \\
\hline RHD3 & (9) RABG3f & & \\
\hline
\end{tabular}

Viruses

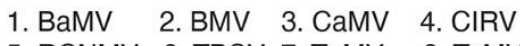

5. RCNMV 6. TBSV 7. TUMV 8. TOMV

9. CNV

Figure 2. Schematic representation of changes in subcellular localization after viral infection. Representative host proteins and plant viruses that induce relocation in more than two proteins are illustrated. Host proteins are color-coded with spheres. Viruses are indicated by numbers. (A) Changes in host cytoplasmic proteins and (B) changes in host proteins naturally localized to organelles, and their movement in the presence of a virus. 


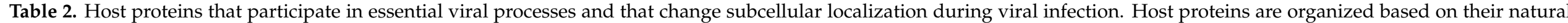
distribution in the absence of virus.

\begin{tabular}{|c|c|c|c|c|c|c|c|c|c|c|}
\hline Virus & $\begin{array}{l}\text { Viral Protein } \\
\text { or RNA }\end{array}$ & Host Protein & Host & $\begin{array}{l}\text { Movement of } \\
\text { Host } \\
\text { Protein into }\end{array}$ & Role & Initial Detection & $\begin{array}{l}\text { Mechanism of } \\
\text { Interaction }\end{array}$ & $\begin{array}{c}\text { Experimental } \\
\text { System for } \\
\text { Detecting of New } \\
\text { Localization Sites * }\end{array}$ & $\begin{array}{c}\text { Method of } \\
\text { Observation: Time }\end{array}$ & Reference \\
\hline \multicolumn{11}{|c|}{ Cytoplasmic proteins } \\
\hline CaMV & TAV & RISP & Arabidopsis thaliana & $\begin{array}{l}\text { Inclusion bodies } \\
\text { (cytoplasmic } \\
\text { and nuclear) }\end{array}$ & $\begin{array}{l}\text { Stimulates translation } \\
\text { re-initiation }\end{array}$ & Yeast two hybrid & Protein-protein & Brassica rapa leaves & $\begin{array}{l}\text { Immunofluorescence } \\
\text { and confocal } \\
\text { microscopy: } 15 \mathrm{dpi}\end{array}$ & [45] \\
\hline BaMV & $\begin{array}{c}155 \mathrm{kDa} \text { and } \\
3^{\prime} \text { UTR }\end{array}$ & HSP90 & Nicotiana benthamiana & Chloroplast & $\begin{array}{l}\text { Formation of } \\
\text { replication } \\
\text { compartments }\end{array}$ & $\begin{array}{l}\text { Partially purified } \\
\quad \text { replicase }\end{array}$ & $\begin{array}{c}\text { Protein-protein } \\
\text { and } \\
\text { RNA-protein }\end{array}$ & $\begin{array}{l}\text { Saccharomyces } \\
\text { cerevisiae and } \\
\text { Escherichia coli }\end{array}$ & $\begin{array}{l}\text { Yeast two hybrid, } \\
\text { GST-pull down }\end{array}$ & [46] \\
\hline \multirow{2}{*}{ BMV } & $1 \mathrm{a}$ & ESCRT- III & S. cerevisiae & Perinuclear ER & $\begin{array}{c}\text { Formation of } \\
\text { replication } \\
\text { compartments }\end{array}$ & Yeast genetic analysis & Protein-protein & S. cerevisiae & $\begin{array}{l}\text { Immunofluorescence } \\
\text { and confocal } \\
\text { microscopy: } 48 \mathrm{~h}\end{array}$ & [48] \\
\hline & $1 \mathrm{a}$ and $2 \mathrm{~b}$ & LSM1 & S. cerevisiae & ER & $\begin{array}{c}\text { Promotes viral RNA } \\
\text { translation }\end{array}$ & Yeast mutagenesis & Protein-protein & S. cerevisiae & $\begin{array}{l}\text { Immunofluorescence } \\
\text { and confocal } \\
\text { microscopy: } 48 \mathrm{~h}\end{array}$ & {$[49,50]$} \\
\hline \multirow{2}{*}{ CIRV } & p36 & ESCRT-I & N. benthamiana & Mitochondria & $\begin{array}{l}\text { Formation of } \\
\text { replication } \\
\text { compartments }\end{array}$ & Split ubiquitin assay & Protein-protein & S. cerevisiae & $\begin{array}{l}\text { Immunofluorescence } \\
\text { and confocal } \\
\text { microscopy: } \\
15-45 \mathrm{~min} \\
\end{array}$ & [51] \\
\hline & p36 & ORP & $\begin{array}{l}\text { N. benthamiana and } \\
\text { S. cerevisiae }\end{array}$ & $\begin{array}{l}\text { Mitochondria } \\
\text { and ER }\end{array}$ & $\begin{array}{c}\text { Formation of } \\
\text { replication } \\
\text { compartments }\end{array}$ & Yeast two hybrid & Protein-protein & $\begin{array}{c}\text { N. benthamiana } \\
\text { leaves }\end{array}$ & BiFC: $48 \mathrm{~h}$ & [52] \\
\hline PepMV & p26 & Catalase 1 & Solanum lycopersicum & $\begin{array}{l}\text { Cytoplasm } \\
\text { and nucleus }\end{array}$ & $\begin{array}{l}\text { Antagonist to } \\
\text { antiviral response }\end{array}$ & Yeast two hybrid & Protein-protein & $\begin{array}{c}\text { N. benthamiana } \\
\text { leaves }\end{array}$ & $\begin{array}{c}\mathrm{BiFC} \\
\text { immunolabeling, and } \\
\text { electron microscopy: } \\
3-4 \mathrm{dpi}\end{array}$ & [53] \\
\hline PVX & TGB12K & TIP & Nicotiana tabacum & Peripheral bodies & $\begin{array}{c}\text { Regulates } \\
\text { plasmodesmata } \\
\text { opening }\end{array}$ & Yeast two hybrid & Protein-protein & $\begin{array}{l}\text { N. benthamiana } \\
\text { leaves }\end{array}$ & $\begin{array}{l}\text { Confocal microscopy: } \\
3 \text { dpi }\end{array}$ & [54] \\
\hline \multirow{2}{*}{ RCNMV } & p27 & HSP70 & N. benthamiana & ER & $\begin{array}{l}\text { Formation of } \\
\text { replication } \\
\text { compartments }\end{array}$ & Affinity purification & Protein-protein & $\begin{array}{l}\text { N. benthamiana } \\
\text { leaves }\end{array}$ & $\begin{array}{l}\text { Confocal microscopy: } \\
3 \text { dpi }\end{array}$ & [21] \\
\hline & p27 & NbRACK1 & N. benthamiana & $\begin{array}{l}\text { ER-derived } \\
\text { aggregates }\end{array}$ & $\begin{array}{l}\text { Increases ROS to } \\
\text { benefit the virus }\end{array}$ & $\begin{array}{c}\text { Co- } \\
\text { immunoprecipitation }\end{array}$ & Protein-protein & $\begin{array}{c}\text { N. benthamiana } \\
\text { leaves }\end{array}$ & BiFC: 4 dpi & [55] \\
\hline RSV & $337 \mathrm{kDa}$ & HSP20 & $\begin{array}{l}\text { N. benthamiana and } \\
\text { Oryza sativa }\end{array}$ & Nucleus & $\begin{array}{l}\text { Antagonist to } \\
\text { antiviral response }\end{array}$ & Yeast two hybrid & Protein-protein & $\begin{array}{c}\text { N. benthamiana } \\
\text { leaves }\end{array}$ & BiFC: $48 \mathrm{~h}$ & [56] \\
\hline
\end{tabular}


Table 2. Cont

\begin{tabular}{|c|c|c|c|c|c|c|c|c|c|c|}
\hline Virus & $\begin{array}{l}\text { Viral Protein } \\
\text { or RNA }\end{array}$ & Host Protein & Host & $\begin{array}{l}\text { Movement of } \\
\text { Host } \\
\text { Protein into }\end{array}$ & Role & Initial Detection & $\begin{array}{l}\text { Mechanism of } \\
\text { Interaction }\end{array}$ & $\begin{array}{c}\text { Experimental } \\
\text { System for } \\
\text { Detecting of New } \\
\text { Localization Sites * }\end{array}$ & $\begin{array}{l}\text { Method of } \\
\text { Observation: Time }\end{array}$ & Reference \\
\hline \multirow{5}{*}{ TBSV } & p33 & eEF1A & S. cerevisiae & $\begin{array}{c}\text { Peroxisomal } \\
\text { membrane }\end{array}$ & Stabilization of p33 & $\begin{array}{l}\text { Purified replicase } \\
\text { proteomics }\end{array}$ & Protein-protein & S. cerevisiae & Co-purification & {$[35,57]$} \\
\hline & p33 & ESCRT-I & N. benthamiana & $\begin{array}{l}\text { Peroxisomal } \\
\text { membrane }\end{array}$ & $\begin{array}{c}\text { Formation of } \\
\text { replication } \\
\text { compartments }\end{array}$ & Split ubiquitin assay & Protein-protein & S. cerevisiae & $\begin{array}{l}\text { Confocal microscopy: } \\
15-45 \mathrm{~min}\end{array}$ & [58] \\
\hline & p33 & GAPDH & $\begin{array}{l}\text { N. benthamiana and } \\
\text { S. cerevisiae }\end{array}$ & $\begin{array}{l}\text { Peroxisomal } \\
\text { membrane }\end{array}$ & $\begin{array}{l}\text { Viral genomic } \\
\text { RNA synthesis }\end{array}$ & $\begin{array}{l}\text { Purified replicase } \\
\text { proteomics }\end{array}$ & $\begin{array}{l}\text { Indirect: } \\
\text { mediated by } \\
\text { p92pol }\end{array}$ & S. cerevisiae & $\begin{array}{l}\text { Confocal microscopy: } \\
16 \mathrm{~h}\end{array}$ & [59] \\
\hline & $\begin{array}{l}\text { p33 and } \\
\text { p92 }\end{array}$ & HSP70 & S. cerevisiae & $\begin{array}{l}\text { Peroxisomal } \\
\text { membrane }\end{array}$ & $\begin{array}{l}\text { Formation of } \\
\text { replication } \\
\text { compartments }\end{array}$ & Reconstitution assay & Protein-protein & S. cerevisiae & $\begin{array}{l}\text { Confocal microscopy: } \\
16 \text { and } 24 \mathrm{~h}\end{array}$ & {$[60,61]$} \\
\hline & p33 & ORP & S. cerevisiae & $\begin{array}{l}\text { Peroxisome } \\
\text { and ER }\end{array}$ & $\begin{array}{c}\text { Formation of } \\
\text { replication } \\
\text { compartments }\end{array}$ & Affinity purification & Protein-protein & $\begin{array}{l}\text { S. cerevisiae and } N \text {. } \\
\text { benthamiana leaves }\end{array}$ & BiFC: 2 dpi & [52] \\
\hline TMV & $\begin{array}{l}\text { RdRp and } 3^{\prime} \\
\text { UTR }\end{array}$ & eEF1A & N. tabacum & $\begin{array}{l}\text { Replication } \\
\text { compartment }\end{array}$ & $\begin{array}{l}\text { Formation of } \\
\text { replication } \\
\text { compartments and } \\
\text { cell-to-cell movement }\end{array}$ & Pull-down assay & Protein-protein & N. tabacum & $\begin{array}{c}\text { Immunoprecipitation: } \\
4 \mathrm{dpi}\end{array}$ & [62] \\
\hline \multirow{4}{*}{ TuMV } & VPg & AtRH8 & $\begin{array}{l}\text { Prunus persica and } \\
\text { A. thaliana }\end{array}$ & $\begin{array}{l}\text { Chloroplast } \\
\text { membrane }\end{array}$ & $\begin{array}{l}\text { Formation of } \\
\text { replication } \\
\text { compartments }\end{array}$ & Yeast two hybrid & Protein-protein & $\begin{array}{l}\text { N. benthamiana } \\
\text { leaves }\end{array}$ & BiFC: 2 and $10 \mathrm{dpi}$ & [63] \\
\hline & $6 \mathrm{~K} 2$ & AtRH9 & A. thaliana & $\begin{array}{l}\text { Chloroplast } \\
\text { membrane }\end{array}$ & $\begin{array}{l}\text { Formation of } \\
\text { replication } \\
\text { compartments }\end{array}$ & Confocal microcopy & Protein-protein & $\begin{array}{l}\text { N. benthamiana } \\
\text { leaves }\end{array}$ & $\begin{array}{l}\text { Confocal microscopy: } \\
72 \mathrm{~h}\end{array}$ & {$[64]$} \\
\hline & $\mathrm{VPg}$ and $\mathrm{NIb}$ & eEF1A & A. thaliana & $\begin{array}{l}\text { ER-derived } \\
\text { replication } \\
\text { compartments }\end{array}$ & $\begin{array}{c}\text { Viral RNA } \\
\text { translation, formation } \\
\text { of replication } \\
\text { compartments }\end{array}$ & $\begin{array}{l}\text { Tandem affinity } \\
\text { purification }\end{array}$ & Protein-protein & $\begin{array}{l}\text { N. benthamiana } \\
\text { leaves }\end{array}$ & $\begin{array}{l}\text { Immunofluorescence } \\
\text { and confocal } \\
\text { microscopy: } 4-5 \text { dpi }\end{array}$ & [65] \\
\hline & $\mathrm{VPg}$ & eIF(iso) $4 \mathrm{e}$ & A. thaliana & $\begin{array}{l}\text { ER and } \\
\text { chloroplasts }\end{array}$ & $\begin{array}{c}\text { Viral RNA } \\
\text { translation, formation } \\
\text { of replication } \\
\text { compartments }\end{array}$ & Pull-down assay & Protein-protein & $\begin{array}{c}N . \text { benthamiana } \\
\text { leaves }\end{array}$ & $\begin{array}{l}\text { Immunofluorescence } \\
\text { and confocal } \\
\text { microscopy: } 2-4 \mathrm{dpi}\end{array}$ & [65] \\
\hline \multirow[t]{2}{*}{ TuMV } & $\mathrm{NIb}$ & HSP70 & A. thaliana & $\begin{array}{l}\text { Nucleus and } \\
\text { replication } \\
\text { compartments in } \\
\text { the ER }\end{array}$ & $\begin{array}{l}\text { Formation of } \\
\text { replication } \\
\text { compartments, } \\
\text { regulation of } \\
\text { Nlb activity }\end{array}$ & $\begin{array}{l}\text { Tandem affinity } \\
\text { purification }\end{array}$ & $\begin{array}{l}\text { Indirect: } \\
\text { mediated by } \\
\text { RdRp }\end{array}$ & $\begin{array}{l}\text { N. benthamiana } \\
\text { leaves }\end{array}$ & $\begin{array}{c}\text { Confocal microscopy: } \\
2-4 \text { dpi }\end{array}$ & [20] \\
\hline & VPg & РABP2 & Brassica perviridis & Nucleus and ER & $\begin{array}{l}\text { Formation of } \\
\text { replication } \\
\text { compartments }\end{array}$ & $\begin{array}{l}\text { Subcellular } \\
\text { fractionation }\end{array}$ & Protein-protein & $\begin{array}{l}\text { N. benthamiana } \\
\text { leaves }\end{array}$ & $\begin{array}{l}\text { Confocal microscopy: } \\
4-5 \mathrm{dpi}\end{array}$ & [66] \\
\hline
\end{tabular}


Table 2. Cont.

\begin{tabular}{|c|c|c|c|c|c|c|c|c|c|c|}
\hline Virus & $\begin{array}{l}\text { Viral Protein } \\
\text { or RNA }\end{array}$ & Host Protein & Host & $\begin{array}{l}\text { Movement of } \\
\text { Host } \\
\text { Protein into }\end{array}$ & Role & Initial Detection & $\begin{array}{l}\text { Mechanism of } \\
\text { Interaction }\end{array}$ & $\begin{array}{c}\text { Experimental } \\
\text { System for } \\
\text { Detecting of New } \\
\text { Localization Sites* }\end{array}$ & $\begin{array}{c}\text { Method of } \\
\text { Observation: Time }\end{array}$ & Reference \\
\hline \multirow[t]{2}{*}{ ToMV } & $\begin{array}{l}130 \mathrm{~K} \text { and } \\
180 \mathrm{~K}\end{array}$ & eEF1A & N. tabacum & ER membranes & $\begin{array}{c}\text { Viral RNA } \\
\text { translation, formation } \\
\text { of replication } \\
\text { compartments }\end{array}$ & $\begin{array}{l}\text { Subcellular } \\
\text { fractionation }\end{array}$ & Protein-protein & $\begin{array}{l}\text { Transgenic N. } \\
\text { tabacum BY-2 } \\
\text { protoplast }\end{array}$ & Affinity purification & [67] \\
\hline & $\begin{array}{l}130 \mathrm{~K} \text { and } \\
180 \mathrm{~K}\end{array}$ & HSP70 & N. tabacum & ER membranes & $\begin{array}{l}\text { Formation of } \\
\text { replication } \\
\text { compartments }\end{array}$ & $\begin{array}{l}\text { Subcellular } \\
\text { fractionation }\end{array}$ & Protein-protein & $\begin{array}{l}\text { Transgenic } N . \\
\text { tabacum } \mathrm{BY}-2 \\
\text { protoplast }\end{array}$ & Affinity purification & [67] \\
\hline TYLCV & $\mathrm{CP}$ & HSP70 & S. lycopersicum & $\begin{array}{l}\text { Cytoplasm and } \\
\text { nucleus } \\
\text { aggregates }\end{array}$ & Movement of virions & $\begin{array}{l}\text { Subcellular } \\
\text { fractionation }\end{array}$ & Protein-protein & $\begin{array}{l}\text { S. lycopersicum } \\
\text { leaves }\end{array}$ & $\begin{array}{l}\text { Immunodetection } \\
\text { and confocal } \\
\text { microscopy: } 28 \text { or } \\
49 \mathrm{dpi}\end{array}$ & [68] \\
\hline \multicolumn{11}{|c|}{ Endosomal proteins } \\
\hline CIRV & p36 & RAB5-GTPase & A. thaliana & Mitochondria & $\begin{array}{l}\text { Formation of } \\
\text { replication } \\
\text { compartments }\end{array}$ & Yeast two hybrid & Protein-protein & $\begin{array}{l}\text { N. benthamiana } \\
\text { leaves }\end{array}$ & BiFC: 2 dpi & [69] \\
\hline $\mathrm{CNV}$ & p33 & RAB5-GTPase & A. thaliana & Peroxisome & $\begin{array}{l}\text { Formation of } \\
\text { replication } \\
\text { compartments }\end{array}$ & Yeast two hybrid & Protein-protein & $\begin{array}{l}\text { N. benthamiana } \\
\text { leaves }\end{array}$ & BiFC: 2 dpi & [69] \\
\hline TBSV & p33 & RAB5-GTPase & A. thaliana & Peroxisome & $\begin{array}{l}\text { Formation of } \\
\text { replication } \\
\text { compartments }\end{array}$ & Yeast two hybrid & Protein-protein & $\begin{array}{l}\text { N. benthamiana } \\
\text { leaves }\end{array}$ & BiFC: 2 dpi & [69] \\
\hline \multicolumn{11}{|c|}{ Endoplasmic reticulum proteins } \\
\hline BMV & 1a & RHP & S. cerevisiae & $\begin{array}{l}\text { Perinuclear ER } \\
\text { membrane }\end{array}$ & $\begin{array}{l}\text { Formation of } \\
\text { replication } \\
\text { compartments }\end{array}$ & Immunoprecipitation & Protein-protein & S. cerevisiae & $\begin{array}{l}\text { Co-Ip and confocal } \\
\text { microscopy: } 12 \text { dpi }\end{array}$ & [70] \\
\hline \multirow{2}{*}{ TuMV } & $6 \mathrm{~K} 2$ & SNARE -SYP71 & A. thaliana & Chloroplast & $\begin{array}{c}\text { Fusion replication } \\
\text { compartments in } \\
\text { chloroplast }\end{array}$ & Confocal microscopy & $\begin{array}{l}\text { Indirect: } \\
\text { mediated by } \\
\text { Vap27-1 }\end{array}$ & $\begin{array}{c}\text { N. benthamiana } \\
\text { leaves }\end{array}$ & $\begin{array}{l}\text { Confocal microscopy: } \\
48 \mathrm{~h}\end{array}$ & [71] \\
\hline & $6 \mathrm{~K} 2$ & RHD3 & A. thaliana & $\begin{array}{l}\text { Replication } \\
\text { compartments }\end{array}$ & $\begin{array}{c}\text { Maturation of } \\
\text { replication } \\
\text { compartments }\end{array}$ & Yeast two hybrid & Protein-protein & N. tabacum leaves & $\begin{array}{c}\text { Confocal microscopy: } \\
7 \mathrm{dpi}\end{array}$ & [28] \\
\hline \multicolumn{11}{|c|}{ Golgi apparatus proteins } \\
\hline $\mathrm{BaMV}$ & NA & RABG3f & N. benthamiana & $\begin{array}{c}\text { Replication } \\
\text { compartments }\end{array}$ & $\begin{array}{l}\text { Formation and } \\
\text { movement of } \\
\text { replication } \\
\text { compartments }\end{array}$ & Immunofluorescence & Unknown & $\begin{array}{c}\text { N. benthamiana } \\
\text { leaves }\end{array}$ & $\begin{array}{l}\text { Confocal microscopy: } \\
5 \mathrm{dpi}\end{array}$ & [72] \\
\hline
\end{tabular}


Table 2. Cont.

\begin{tabular}{|c|c|c|c|c|c|c|c|c|c|c|}
\hline Virus & $\begin{array}{l}\text { Viral Protein } \\
\text { or RNA }\end{array}$ & Host Protein & Host & $\begin{array}{c}\text { Movement of } \\
\text { Host } \\
\text { Protein into }\end{array}$ & Role & Initial Detection & $\begin{array}{l}\text { Mechanism of } \\
\text { Interaction }\end{array}$ & $\begin{array}{c}\text { Experimental } \\
\text { System for } \\
\text { Detecting of New } \\
\text { Localization Sites * }\end{array}$ & $\begin{array}{c}\text { Method of } \\
\text { Observation: Time }\end{array}$ & Reference \\
\hline CaMV & MP & $\mu \mathrm{A}$-adaptin & A. thaliana & $\begin{array}{c}\text { Plasma } \\
\text { membrane }\end{array}$ & MP trafficking & GST pull-down & Protein-protein & $\begin{array}{c}\text { Escherichia coli and } \\
\text { A. thaliana }\end{array}$ & GST-pull down & [73] \\
\hline RCNMV & p27 & ARF1 & $\begin{array}{l}\text { N. benthamiana and } \\
\text { N. tabacum }\end{array}$ & ER & $\begin{array}{c}\text { Formation of } \\
\text { replication } \\
\text { compartments }\end{array}$ & Affinity purification & Protein-protein & $\begin{array}{l}\text { N. tabacum } \\
\text { protoplast }\end{array}$ & $\begin{array}{c}\text { Confocal microscopy: } \\
16 \mathrm{~h}\end{array}$ & [74] \\
\hline \multicolumn{11}{|c|}{ Plasma membrane proteins } \\
\hline CaMV & p6 & AtSRC2.2 & A. thaliana & $\begin{array}{l}\text { Inclusion bodies } \\
\text { (cytoplasmic and } \\
\text { nuclear) }\end{array}$ & $\begin{array}{l}\text { Cell-to-cell } \\
\text { movement }\end{array}$ & Yeast two hybrid & Protein-protein & $\begin{array}{c}\text { N. benthamiana } \\
\text { leaves }\end{array}$ & $\begin{array}{c}\text { Co- } \\
\text { immunoprecipitation } \\
\text { and confocal } \\
\text { microscopy: } 3 \mathrm{dpi}\end{array}$ & [75] \\
\hline RCNMV & p27 & RBOHB & N. benthamiana & $\begin{array}{l}\text { Perinuclear } \\
\text { ER-derived } \\
\text { aggregates }\end{array}$ & ROS synthesis & Immunoprecipitation & Protein-protein & $\begin{array}{l}\text { N. benthamiana } \\
\text { leaves }\end{array}$ & $\begin{array}{c}\text { Confocal microscopy } \\
\text { andBiFC } \\
: 4 \mathrm{dpi}\end{array}$ & [76] \\
\hline TVBMV & $\begin{array}{l}\text { P3N-PIPO } \\
\text { and CI }\end{array}$ & DREPP & N. benthamiana & Plasmodesmata & $\begin{array}{l}\text { Cell-to-cell } \\
\text { movement }\end{array}$ & Yeast two hybrid & Protein-protein & $\begin{array}{c}\text { N. benthamiana } \\
\text { leaves }\end{array}$ & BiFC: 2 and 5 dpi & [40] \\
\hline \multicolumn{11}{|c|}{ Plasma membrane proteins } \\
\hline TVCV & MP & SYTA & A. thaliana & Plasmodesmata & $\begin{array}{c}\text { Alters } \\
\text { plasmodesmata } \\
\text { permeability }\end{array}$ & Confocal microscopy & Protein-protein & $\begin{array}{l}\text { N. benthamiana } \\
\text { leaves }\end{array}$ & $\begin{array}{c}\text { Confocal microscopy } \\
\text { and BiFC }\end{array}$ & {$[34]$} \\
\hline \multicolumn{11}{|c|}{ Nuclear proteins } \\
\hline GRV & ORF3 & Fibrillarin & $\begin{array}{l}\text { N. benthamiana and } \\
\text { A. thaliana }\end{array}$ & Cytoplasm & Systemic movement & $\begin{array}{l}\text { Affinity purification } \\
\text { and chromatography }\end{array}$ & Protein-protein & $\begin{array}{c}\text { N. benthamiana } \\
\text { leaves and E. coli }\end{array}$ & Far Western blotting & [27] \\
\hline RCNMV & p27 & HSP90 & N. benthamiana & ER & $\begin{array}{l}\text { Formation of } \\
\text { replication } \\
\text { compartments }\end{array}$ & $\begin{array}{l}\text { Partially purified } \\
\text { replicase }\end{array}$ & Protein-protein & $\begin{array}{l}\text { N. benthamiana } \\
\text { leaves }\end{array}$ & BiFC: 3 and 4 dpi & [21] \\
\hline TMV & MP & NTH201 & N. tabacum & $\begin{array}{l}\text { Cytoplasm and } \\
\text { plasmodesmata }\end{array}$ & $\begin{array}{c}\text { Enhances replication } \\
\text { compartment } \\
\text { formation }\end{array}$ & Confocal microscopy & Indirect & $\begin{array}{l}\text { N. benthamiana } \\
\text { leaves }\end{array}$ & $\begin{array}{l}\text { Confocal microscopy: } \\
\qquad 24 \mathrm{~h}\end{array}$ & [78] \\
\hline TBSV & p19 & ALY & $\begin{array}{l}\text { N. benthamiana and } \\
\text { A. thaliana }\end{array}$ & Cytoplasm & Co-factor & Yeast two hybrid & Protein-protein & $\begin{array}{c}\text { N. benthamiana } \\
\text { leaves }\end{array}$ & $\begin{array}{c}\text { Confocal microscopy: } \\
3 \mathrm{dpi}\end{array}$ & [79] \\
\hline \multicolumn{11}{|c|}{ Vacuolar proteins } \\
\hline ToMV & $\begin{array}{l}130 \mathrm{~K} \text { and } \\
180 \mathrm{~K}\end{array}$ & $\begin{array}{l}\text { TOM1 } \\
\text { TOM3 }\end{array}$ & $\begin{array}{l}\text { A. thaliana and } \\
\text { N. tabacum }\end{array}$ & ER & $\begin{array}{l}\text { Formation and } \\
\text { anchoring of } \\
\text { replication } \\
\text { compartments }\end{array}$ & Membrane flotation & Protein-protein & $\begin{array}{l}\text { S. cerevisiae and } \\
\text { N. tabacum leaves }\end{array}$ & $\begin{array}{l}\text { Yeast two hybrid and } \\
\text { subcellular } \\
\text { fractionation at } 2 \mathrm{dpi}\end{array}$ & {$[80,81]$} \\
\hline
\end{tabular}

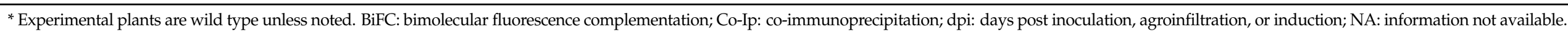




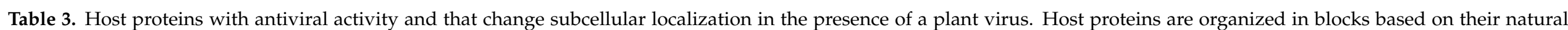
distribution in the absence of virus.

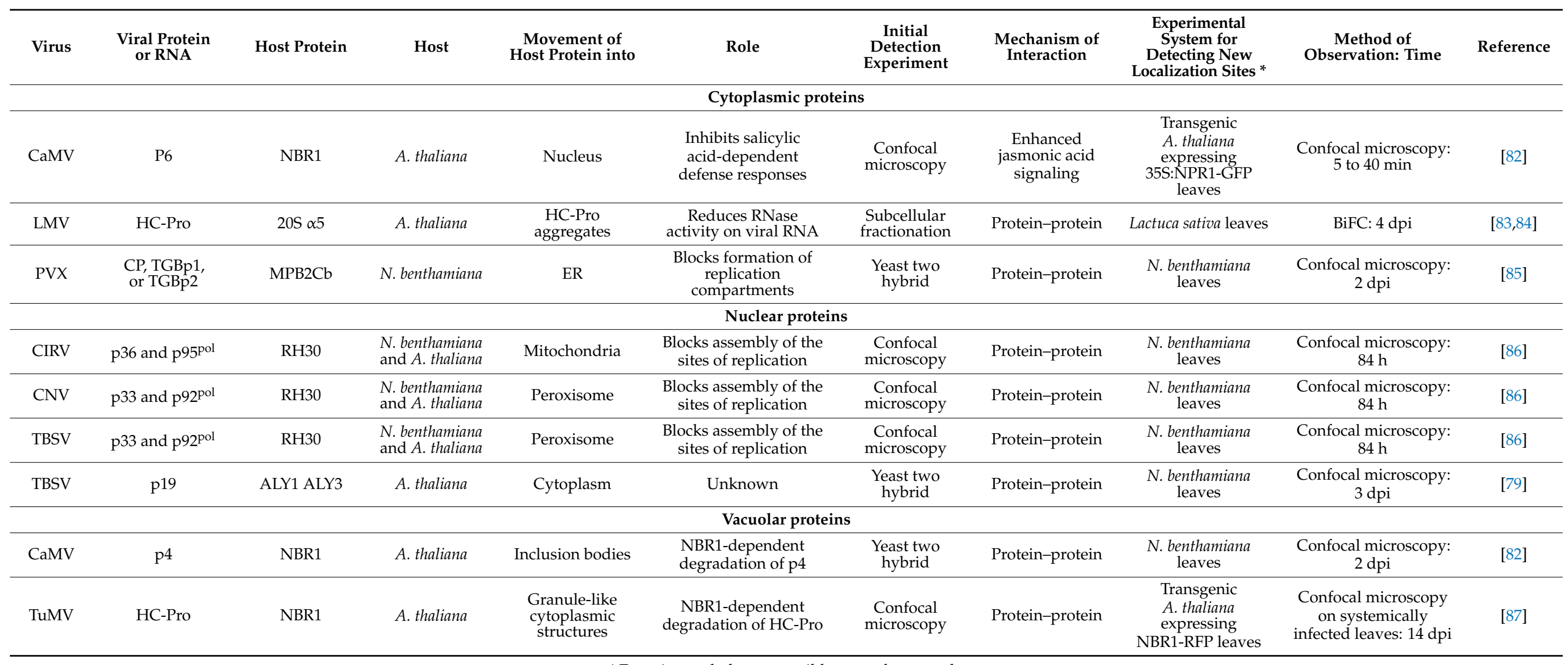

* Experimental plants are wild type unless noted. 


\subsection{Heat Shock Proteins (HSPs)}

HSPs are highly conserved in plants and animals. They are chaperones that protect other proteins from degradation and facilitate protein trafficking across membranes. HSPs have several physiological functions in plants, including protection from stress caused by heat, cold, light, heavy metals, salts, and ozone. HSPs are mainly located in the cytosolic part of the cell, and in some cases, in the nucleus, chloroplasts, or ER $[88,89]$. Several HSPs are chaperones of viral proteins, have essential roles in virus replication $[20,21,56]$, and are recruited to the sites of virus replication (Table 2). Notable examples are discussed below.

HSP70 moves from the cytoplasm to the nucleus during tomato yellow leaf curl virus (TYLCV, single-strand DNA genome) infection [68], and to the ER compartments during TuMV (single positive-strand RNA genome) infection [20]. Downregulation of HSP70 results in the reduced accumulation of TYLCV genomic DNA in infected plants [68]. Both HSP70 and HSP90 localize mainly in the cytoplasm, and upon red clover necrotic mosaic virus (RCNMV, single positive-strand RNA genome) infection, HSP70 and HSP90 were detected in the ER (Table 2). Movement occurred through interactions with p27, a component of the virus replication compartments $[31,74]$. Without detectable physiological or developmental defects in the plants, the downregulation of HSP70 and HSP90 by virus-induced gene silencing prevented infection by RCNMV, confirming there are susceptibility genes [21,31]. Moreover, during infection with bamboo mosaic virus (BaMV, single positive-strand RNA genome), HSP90 enhances the formation of ribonucleoprotein complexes and facilitates their entry into the chloroplast, thus moving to the chloroplasts and playing an important role in BaMV replication [90]. HSP20 antagonizes the antiviral response by moving into the nucleus through interaction with the RNA-dependent RNA polymerase (RdRp) of rice stripe virus (RSV, single negative-strand RNA genome), blocking the recruitment of viral RNA to stress granules and, thus, blocking the degradation of viral RNA and enhancing viral RNA translation [56].

\subsection{Endosomal Sorting Complexes Required for Transport (ESCRTs)}

ESCRTs are peripheral membrane proteins in plant, mammalian, and yeast cells and play important roles in autophagy, sorting of ubiquitinated receptors, and in cytokinesis. They are also involved in the detachment of membrane vesicles, viral budding, and in the formation of the sites of virus replication [48,58,91]. ESCRT-I and ESCRT-III move from the cytoplasm to the sites of replication formed by TBSV (single positive-strand RNA genome) in the peroxisome and by BMV (single positive-strand RNA genome) in the perinuclear ER (Table 2) $[18,48,58]$. Their recruitment to the sites of virus replication is mediated by their interaction with TBSV replication protein $\mathrm{p} 33$ or BMV replication protein 1a (Table 2). ESCRT proteins are proposed participate in bending membranes to achieve the spherical shape of the compartments that function as sites of replication for both viruses $[18,48,58]$. Thus, the absence of ESCRT proteins in yeast cells, and their downregulation in plants, resulted in a reduction in the accumulation of BMV and TBSV, respectively $[18,48,58]$.

\subsection{Translation Factors}

Viruses are dependent on the host machinery to translate their RNAs into proteins. Several viruses require eukaryote initiation factors Poly A binding protein2 (PABP2), eukaryote initiation factor eIF (iso) $4 \mathrm{e}$, eIF4e, and elongation factor eEF(1A). During viral infection, these proteins move from the cytoplasm to the sites of TuMV replication $[5,45,92]$ (Table 2). Re-initiation supporting proteins (RISPs) move from the cytoplasm to transactivator viroplasmin (TAV) aggregates $[45,93]$ and are necessary for cauliflower mosaic virus $(\mathrm{CaMV})$ infection $[65,66]$. Additionally, some translation factors contribute to the cell-to-cell movement and systemic spread of the virus [92]. The role of the initiation, elongation, and re-initiation factors in the sites of virus replication and in virus movement is unclear. 


\subsection{Asp-Glu-Ala-Asp (DEAD)-Box RNA Helicases (RHAs)}

DEAD-box RNA helicases (RHAs) are a large family of RNA helicases involved in all steps of RNA metabolism. They are required for transcription, mRNA splicing and translation, RNA modification and transport, ribosome biogenesis, ribonucleoprotein complex assembly, and mRNA degradation [94]. RHAs are also involved in the response to biotic stress and in abiotic stress tolerance [95].

Several RHAs contribute to the translation and replication of viral RNA and change their localization upon viral infection [96,97]. The RNA helicases, AtRH8 and AtRH9, move from the cytoplasm to the sites of TuMV replication in the chloroplast in A. thaliana (Table 2). Migration into the chloroplast is mediated by viral proteins. AtRH8 interacts with virus-linked protein VPg [63], while AtRH9 interacts with potyvirus membrane protein $6 \mathrm{~K} 2$ [64]. In mutant plants lacking either AtRH8 or AtRH9, accumulation of TuMV is reduced $[63,64]$.

\subsection{Glyceraldehyde 3-Phosphate Dehydrogenase (GAPDH)}

GAPDH is a catalytic enzyme involved in glycolysis and mRNA binding. After infection with TBSV, GAPDH moves from the cytoplasm to the peroxisomal membrane and into the sites of TBSV replication. GAPDH is responsible for maintaining the ratio between positive- and negative-strand RNA genomes. Downregulation of GAPDH in $N$. benthamiana plants caused a fourfold reduction in the accumulation of TBSV and tobacco mosaic virus (TMV, single positive-strand RNA genome), pointing to a required role of this protein in both viruses [59]. In contrast, GAPDH has an antiviral role against BaMV and its satellite (satBaMV) as its downregulation in N. benthamiana plants resulted in an increase in BaMV and satBaMV RNA accumulation, while its overexpression reduced the accumulation of BaMV and satBaMV. The subcellular localization of GAPDH does not change during infection with BaMV or satBaMV [98].

\subsection{Glutathione Transferase U4 (GSTU4)}

GSTU4 belongs to the family of plant glutathione transferases (GSTs), which catalyze the reduction of hydroperoxides formed during oxidative stress, participate in ultravioletinducible cell signaling pathways, and in the regulation of apoptosis [99]. During infection with BaMV, GSTU4 is upregulated, interacts with the $3^{\prime}$ untranslated region (UTR) in BaMV genomic RNA, moves from the cytoplasm to the sites of virus replication in the chloroplasts, and enhances the synthesis of negative-strand RNA. Downregulation of GSTU4 caused a reduction in the accumulation of BaMV and potato virus X (PVX, single positive-strand RNA genome) but not in the accumulation of cucumber mosaic virus (CMV, single positivestrand RNA genome) or TMV [47]. In soybean, GSTU10-10 is induced in response to the systemic infection of the plants by soybean mosaic virus (SMV, single positive-strand RNA genome), but no subcellular localization data were reported [100]. Thus, GSTs may have a role in virus susceptibility, mediated by their ability to reduce oxidative stress, which supports viral replication.

\subsection{Other Cytoplasmic Proteins}

Other cytoplasmic proteins with altered localization during viral infection include oxysterol-binding protein-related proteins (ORPs), a yeast RNA-binding protein (LSm1), receptor for activated C kinase 1 (RACK1), and a proteasome protein (20S $\alpha 5)$. ORPs are lipid transfer proteins that participate in vesicular trafficking, lipid metabolism and signaling, non-vesicular sterol transfer, directional sterol transport, and other processes [101]. ORPs facilitate the redistribution of sterols and enhance membrane folding during the formation of the replication sites in the peroxisomes by TBSV, and in the mitochondrial membrane by carnation Italian ringspot virus (CIRV, single positive-strand RNA genome) (Table 2). Deletion of ORPs lowers the efficiency of the viral replicase assembly and activity and resulted in a major reduction in virus accumulation [52]. 
LSm1 is a yeast protein related to the core small nuclear ribonucleoprotein particle (snRNP). LSm1 is involved in BMV RNA de-capping and translation. LSm1 protein is recruited from the cytoplasm to the ER by replication protein 1a and conditions susceptibility to BMV [50].

RACK1 is a cytoplasmic protein involved in the regulation of several plant processes including development, hormone response, and environmental stress response [102]. It is also involved in the innate immune response against fungal and bacterial pathogens [103-105]. During RCNMV infection of $N$. benthamiana, RACK1 interacts with viral replication protein p27 and moves from the cytoplasm to the sites of replication in the ER (Table 2). RACK1 is essential for the p27-mediated induction of reactive oxygen species (ROS) bursts that enhances virus replication. Downregulation of RACK1 resulted in the reduced accumulation of RCNMV RNA [55].

The $20 S \alpha 5$ is a subunit of the ubiquitin-proteasome system with RNAse activity and is involved in the degradation of viral RNA $[83,84]$. After infection with lettuce mosaic virus (LMV, single positive-strand RNA genome), the $20 \mathrm{~S} \alpha 5$ colocalizes with HC-Pro in cytoplasmic aggregates (Table 3). Interaction with HC-Pro and movement into cytoplasmic aggregates blocks the RNAse activity of $20 \mathrm{~S} \alpha 5$, protecting the virus from degradation. Consistent with its antiviral role, downregulation of $20 S \alpha 5$ enhances LMV accumulation [84].

\section{Endosomal Proteins}

Rab GTPases are central regulators of vesicle budding, movement, and fusion [106]. Endosomal protein Rab5-small guanosine triphosphatase (RAB5-GTPase) regulates endosome biogenesis and homotypic and heterotypic fusions [107]. During infection with TBSV and CNV (Table 2), RAB5-GTPase moves to the sites of virus replication in the peroxisomes, or in the mitochondria during CIRV infection [69]. RAB5-GTPase increases the amount of endosomal phospholipid phosphatidylethanolamine needed to form the sites of virus replication and to establish robust virus replication [69].

\section{Endoplasmic Reticulum Proteins}

Several RNA viruses form their sites of replication in endoplasmic reticulum (ER)bound membranes [108], and several ER proteins move into the sites of virus replication formed in other subcellular organelles (Figure 2B). Representative groups are discussed below (Table 2).

\subsection{Soluble N-Ethyl Maleimide Sensitive Factor Adaptor Protein Receptors (SNAREs)}

SNAREs belong to the syntaxin family of proteins that mediate membrane fusion between transport replication compartments and their target membranes [109]. The potyviral $6 \mathrm{~K} 2$ protein induces the formation of ER-derived complexes that subsequently translocate to the chloroplasts, where potyviral replication occurs [71]. A. thaliana SYP71 is a SNARE protein located both in the ER and in the plasma membrane [110], is essential for TuMV replication, and contributes to the movement of replication compartments from the ER to the chloroplast (Table 2). Downregulation of SYP71 inhibits TuMV infection [71].

\subsection{Reticulon Homology Domain Proteins (RHPs)}

RHPs are a family of membrane-shaping proteins that induce and stabilize positively curved peripheral ER membranes and are involved in apoptosis, cell division, and intracellular trafficking [111]. RHPs normally localize to the peripheral ER. During BMV infection, they interact with replication protein 1a, move to the perinuclear ER, and are incorporated into BMV sites of replication. RHPs are essential for the formation of BMV replication compartments. Mutant plants lacking RHPs have a reduced number of replication compartments and an $80 \%$ of reduction in viral replication compared to the wild-type plants [70]. 


\subsection{Root Hair Defective 3 (RHD3)}

RHD3 is a member of the dynamin-like atlastin GTPase family of proteins. It plays a vital role in generating of the interconnected tubular ER network, is required for Golgi distribution and motility in plant cells, and is essential for plant development [112]. RHD3 is essential for the formation, maturation, and intracellular movement of TuMV replication compartments. Interaction with TuMV 6K2 protein moves RHD3 from the ER to the TuMV replication compartments (Table 2). In mutant plants lacking RHD3, replication and systemic movement of TuMV are reduced [28].

\section{Golgi Apparatus Proteins}

Rab guanosine triphosphatase 3f (RABG3f) belongs to the family of Rab GTPases that regulate the intracellular trafficking between organelles [113]. RABG3f is located in the Golgi apparatus and moves to the chloroplast during BaMV infection (Table 2), participates in the formation of the sites of replication, and is required for the efficient infection of in $N$. benthamiana by BaMV. Downregulation of NbRABG3f reduces the accumulation of BaMV [72].

ADP-ribosylation factor (ARF1) 1 is a Golgi body GTPase [114]. During infection with RCNMV, ARF1 interacts with viral protein p27 and is moved into the sites of virus replication on the ER membrane (Table 2). Inhibition of ARF1 activity causes a reduction in RCNMV RNA accumulation [74].

\section{Plasma Membrane Proteins}

Viruses move from cell to cell through plasmodesmata using specialized viral movement proteins and host proteins [115]. Potyviral replication compartments are transported to the plasmodesmata throughout the ER-Golgi secretory pathway and the actomyosin motility system [40]. The phosphatidylinositol phosphates Ca-binding protein (PCaP1) and the developmentally regulated protein (DREPP) are plasma membrane proteins that mediate the cell-to-cell movement of TuMV and tobacco vein banding mosaic virus (TVBMV, single positive-strand RNA genome) respectively, by interacting with P3N-PIPO and CI (cylindric inclusion) proteins (Table 2). The interaction between PCaP1 or DREPP and P3N-PIPO or CI and their relocalization to the plasmodesmata are required for efficient virus replication and local and systemic movement [40,77]. CaMV (single-strand DNA genome) moves through the plasmodesmata as a virion. Cytoplasmic and nuclear inclusion bodies necessary for virion assembly are formed by viral protein P6. AtSRC2.2, a C2 calcium-dependent membrane-targeting protein, is part of the inclusion bodies and has been implicated in CaMV movement [75].

The respiratory burst oxidase homolog $(\mathrm{RBOHB})$ is a plasma membrane protein in the family of plant NADPH oxidases and plays an essential role in ROS production and signaling [116]. During infection of N. benthamiana by RCNMV, RBOHB moves to the perinuclear ER-bound sites of virus replication (Table 2) through interactions with replication protein p27 and is required for robust viral RNA replication [19]. In contrast, during infection with TMV, RBOHB-induced ROS burst has an antiviral effect, with no protein relocalization reported $[117,118]$.

\section{Nuclear Proteins}

DNA viruses replicate in the nucleus [2]. RNA viruses do not enter the nucleus. However, some RNA viruses need nuclear host factors to replicate or move. Fibrillarin is a major nucleolar protein that forms part of Cajal bodies, is a core component of small nucleolar ribonucleoprotein particles, and is required for rRNA processing. Similar to all other umbraviruses, groundnut rosette virus (GRV, single positive-strand RNA genome) does not encode for a coat protein and does not form virions. The lack of a coat protein is compensated by open reading frame 3 (ORF3), and GRV moves as ribonucleoprotein particles. In infected plants, ORF3 cycles from the cytoplasm to the nucleus passing through Cajal bodies and back into the cytoplasm. This movement is dependent on interactions 
between ORF3 and fibrillarin and is required for the formation of ribonucleoprotein particles. Downregulation of fibrillarin through virus-induced gene silencing in N. benthamiana did not affect virus replication or cell-to-cell movement. However, in the absence of fibrillarin ORF3 remained in the Cajal bodies, failed to fuse with the nucleolus, and prevented systemic movement of GRV [27].

Allies of LEF-1 and AML-1 (ALY proteins) belong to a family of nuclear polypeptides involved in mRNA export from the nucleus to the cytosol, in the regulation of plant immunity, in controlling the aperture of stomata, and plant growth and development [119].

During infection by TBSV, two A. thaliana ALYs (AtALY2 and AtALY4) and an $N$. benthamiana ALY protein (NbALY617) move from the nucleus to the cytoplasm (Table 2) by interacting with $\mathrm{P} 19$, a strong silencing suppressor of cytoplasmic distribution that interferes with antiviral gene silencing [79]. The biological significance of this relocation and interaction remains to be determined. In contrast, A. thaliana proteins AtALY1 and AtALY3 and N. benthamiana proteins NbALY615 and NbALY1693 inhibit the silencing suppression activity of P19 (Table 3). This effect is mediated by the sequestration of P19 in the nucleus by nuclear ALY proteins via an RNA-binding motif [120].

Nuclear DEAD-box RNA helicase RH30 interacts with TBSV replication proteins p33 and $\mathrm{p} 92^{\mathrm{pol}}$ and moves from the nucleus to TBSV sites of replication in the peroxisome (Table 3). RH30 inhibits the formation of replication compartments, the recruitment of genomic positive-strand RNA into replication, and RNA synthesis. The antiviral effect has been shown against TBSV, CNV, CIRV, RCNMV, and TMV [86].

\section{Vacuolar Proteins}

Tobamovirus multiplication 1 (TOM1) and TOM3 (Table 2) are vacuolar membrane proteins required for the replication of tobamoviruses. Both interact with the helicaselike domain of replication proteins $130 \mathrm{~K}$ and $180 \mathrm{~K}$ in tomato mosaic virus (ToMV, single positive-strand RNA genome) and participate in the formation and anchoring of replication compartments to the ER $[80,81]$.

Autophagy is a conserved mechanism of protein degradation involved in cell homeostasis. Autophagy may benefit the virus or have antiviral roles [121,122]. Selective autophagy substrate, NBR1, is a cargo receptor protein that suppresses TuMV and CaMV infection by targeting the silencing suppressor HC-Pro and the structural capsid protein P4, respectively. To create an environment favorable to replication and movement, TuMV antagonizes NBR1-dependent autophagy by a mechanism that is dependent on the viral proteins VPg and 6K2 (Table 3). NBR1 is normally found in the autophagosome, cytoplasm, and vacuoles. During TuMV infection, NBR1 moves to virus replication compartments [123]. NBR1 mediates the degradation of TuMV HC-Pro. In turn, TuMV VPg and $6 \mathrm{~K} 2$ proteins counteract NBR1 antiviral effects [87]. However, the role of NBR1 in plant-TuMV interactions is more complex. During TuMV infection of Brassica napus, large amounts of secondary siRNAs are formed from the NBR1 mRNA, which in turn direct cleavage and downregulation of NBR1 mRNA, actin depolymerization factor (ADF), and other transcripts [124].

\section{Conclusions}

Host proteins needed by the virus may be redirected to subcellular compartments where they contribute to essential viral processes, such forming sites of viral replication, RNA synthesis, or virus movement (Table 2 and Figure 2). In the opposite direction, host proteins with antiviral roles may be forced to move away from their natural subcellular localization. Changes in subcellular localization of host proteins are mediated by direct or indirect interactions with viral proteins or RNA (Table 2). However, it is not clear whether accumulation in a new location results from the movement of existing host proteins or from newly synthesized ones.

Changes in the subcellular localization of host proteins have been identified and characterized mainly using experimental hosts $N$. benthamiana, A. thaliana, and S. cerevisiae 
(Figure 1A). The most frequent change is cytoplasmic proteins redirected to virus replication compartments formed in the ER, peroxisome, chloroplast, mitochondria, and nucleus (Figures 1 and 2). In contrast, the number of studies documenting changes in subcellular localization of antiviral proteins is significantly (fivefold) lower (Figure 1B and Table 3). These antiviral proteins block the formation of replication compartments or degrade viral proteins. Subcellular relocalization was needed to perform antiviral activities. Interestingly, in some cases, antiviral activity is inhibited by virus-induced changes in localization (Table 3).

Mutational inactivation or downregulation of proteins that participate in essential viral processes results in lack of infection or reduction of viral RNA accumulation [5,46]. However, genetic changes in the host may cause developmental abnormalities, reduced fitness, or altered physiology, masking the real effect or indirectly affecting virus replication or movement. HSP70, RABG3f, GSTU4, RACK1, GAPDH, AtRH8, and AtRH9 were downregulated by silencing or mutationally inactivated. The source paper explicitly indicated that plants did not show detectable physiological or severe developmental defects compared to the wild-type plants. RACK1-knockdown plants had narrow leaves, categorized as a minor physiological defect [55]. Other publications did not provide information on the phenotype of mutant plants.

The dependence of viruses on host resources at all steps of the infection process puts evolutionary pressure both on the virus and on the host. Virus-host co-evolution might favor interactions that increase both host and virus fitness rather than decreasing fitness of either the host or the virus. Accordingly, it might be to the benefit of viruses to interact with existing processes at their natural location in a non-interfering manner rather than through mechanisms that recruit host proteins away from their natural sites and normal functions, which may potentially lead to disease. All documented cases of changes in subcellular localization (Tables 2 and 3) come from viruses that are pathogenic. Currently, no information is available on the changes, or lack thereof, of host proteins for virus-plant combinations in which the interaction does not lead to disease.

Recruitment of cytoplasmic proteins to the sites of virus replication in membranebound compartments through mechanisms that include direct protein-protein interactions between viral and host proteins and indirectly through membranes, other proteins, or RNA (Table 2, Figure 2) imposes selection pressure on viral proteins to maintain the ability to interact with host proteins. Viral proteins are usually multifunctional. In addition to interacting with other viral proteins or RNA, efficient interaction with host proteins must be maintained. The host might be genetically uniform or diverse. These constraints exert selection pressure on viral proteins to maintain functionality and be able to interact with the cognate host proteins. These observations suggest that interactions between viral and host proteins that are essential at any part of the infection process are also important determinants of virus evolution and host adaptation. Viral proteins might respond to selection pressure by developing a perfect sequence and structure that is functional and able to interact with host proteins that are genetically diverse. Alternatively, viral proteins might respond to selection pressure by incorporating mutationally robust areas coding for structurally flexible domains capable of interacting with host proteins that are genetically diverse. Viruses might be generalists with a wide host range or specialists with a narrow host range. Through co-evolution, in response to selection pressure from the virus, plants might generate diversity in their alleles and/or by incorporating redundant alleles.

This model is illustrated by translation initiation factors and potyviruses. The translation initiation factors, eEF1A and eIF(iso)4e, participate in TuMV viral RNA translation and formation of replication compartments through interactions with $\mathrm{VPg}[5,125]$. Although eIF(iso)4e is necessary for potyvirus infection, it is dispensable for normal plant growth and development [5]. In addition to interacting with eIF(iso)4e, VPg must recognize and interact with TuMV genomic RNA, the RNA-dependent RNA polymerase, and protein 6K1 [5,125]. In connection with its multifunctionality and ability to interact with multiple partners, potyviral VPg is structurally disordered and mutationally robust [126]. Translation initiation 
factors eIF4E are a multigene family. Ten allelic variants of eIF4 were detected in natural pepper populations with varying levels of susceptibility to potyviruses [127]. Accessions resistant to potyvirus infection encoded mutations in eIF4 that disrupted interaction with VPg [127], consistent with the essential role of both VPg and eIF4 in potyvirus-plant interactions and with the model that plants respond to selection pressure by accumulating diversity to buffer the effect of viral infection.

Changes in subcellular localization of host proteins documented to date and summarized here represent bonafide events associated with basic mechanisms of plant-virus interactions. However, these patterns are heavily influenced by the combinations of model hosts and viruses used to develop model experimental systems to identify host factors that affect virus replication (Figure 1A). A large fraction of the host proteins documented were identified using only three viruses BMV, TBSV, and TuMV (single positive-strand RNA, Figure 1D). Reasons for this bias mainly include the availability of infectious clones; well-characterized experimental systems to study virus replication, gene expression, and function; and genetically tractable heterologous hosts in combination with well-developed biochemical approaches for protein expression, purification, and localization $[28,128,129]$. Overexpression of viral proteins in non-natural hosts is a powerful tool to identify potential host proteins that play important roles during infection. It is possible that some of the resulting relocalization may be an artifact of overexpression of individual viral proteins in a heterologous system. However, genetic analyses, virus-induced gene silencing, chemical treatments, or a combination of approaches have been used to validate the requirement of particular host proteins, ruling out the possibility of an experimental artifact $[21,28,68]$. Furthermore, basic information about factors required for viral infection identified in heterologous hosts has been used to engineer resistance in crops. Based on the observation that eukaryote translation initiation factors are susceptibility genes to potyviruses [5], through interaction with potyviral VPg [28], CRISPR-Cas9 was used in tomato to engineer resistance to pepper mottle virus by editing eIF4E1 [130].

New approaches are needed for the genome-wide identification of factors required for the virus or with antiviral activities in natural hosts. Although these approaches are likely to be developed using model experimental systems, it would be of immense benefit to implement them in staple crops. Alternatively, or in addition, these approaches could be directed to particular diseases to which natural resistance is not readily available, such as maize lethal necrosis [131].

Author Contributions: H.G.-R. conceptualized the review. H.G.-R. and R.R.-P. analyzed the data and made tables and figures. H.G.-R., R.R.-P. and K.E.M. wrote the manuscript. All authors have read and agreed to the published version of the manuscript.

Funding: This research was supported by National Institutes of Health (NIH) grant R01GM120108 to H.G.-R. and by the Nebraska Agricultural Experiment Station with funding from the Hatch Act (accession number 1007272) through the United States Department of Agriculture (USDA) National Institute of Food and Agriculture. Open access costs were provided by the same grant.

Institutional Review Board Statement: Not applicable.

Informed Consent Statement: Not applicable.

Acknowledgments: We are grateful to Katherine LaTourrette for critical reading of the manuscript.

Conflicts of Interest: The authors declare no conflict of interest.

\section{References}

1. Den Boon, J.A.; Diaz, A.; Ahlquist, P. Cytoplasmic viral replication complexes. Cell Host Microbe 2010, 8, 77-85. [CrossRef]

2. Ceniceros-Ojeda, E.A.; Rodriguez-Negrete, E.A.; Rivera-Bustamante, R.F. Two populations of viral minichromosomes are present in a geminivirus-infected plant showing symptom remission (recovery). J. Virol. 2016, 90, 3828-3838. [CrossRef] [PubMed]

3. Garcia-Ruiz, H. Susceptibility genes to plant viruses. Viruses 2018, 10, 484. [CrossRef] [PubMed]

4. Ivanov, K.I.; Eskelin, K.; Lohmus, A.; Makinen, K. Molecular and cellular mechanisms underlying potyvirus infection. J. Gen. Virol. 2014, 95, 1415-1429. [CrossRef] 
5. Lellis, A.D.; Kasschau, K.D.; Whitham, S.A.; Carrington, J.C. Loss-of-susceptibility mutants of arabidopsis thaliana reveal an essential role for eif(iso)4e during potyvirus infection. Curr. Biol. 2002, 12, 1046-1051. [CrossRef]

6. Hyodo, K.; Okuno, T. Pathogenesis mediated by proviral host factors involved in translation and replication of plant positivestrand rna viruses. Curr. Opin. Virol. 2016, 17, 11-18. [CrossRef]

7. Garcia-Ruiz, H. Host factors against plant viruses. Mol. Plant. Pathol. 2019, 20, 1588-1601. [CrossRef] [PubMed]

8. Huang, Z.; Yeakley, J.M.; Garcia, E.W.; Holdridge, J.D.; Fan, J.B.; Whitham, S.A. Salicylic acid-dependent expression of host genes in compatible arabidopsis-virus interactions. Plant Physiol. 2005, 137, 1147-1159. [CrossRef]

9. Ascencio-Ibanez, J.T.; Sozzani, R.; Lee, T.J.; Chu, T.M.; Wolfinger, R.D.; Cella, R.; Hanley-Bowdoin, L. Global analysis of arabidopsis gene expression uncovers a complex array of changes impacting pathogen response and cell cycle during geminivirus infection. Plant Physiol. 2008, 148, 436-454. [CrossRef]

10. Chen, S.; Jiang, G.; Wu, J.; Liu, Y.; Qian, Y.; Zhou, X. Characterization of a novel polerovirus infecting maize in china. Viruses 2016, 8, 120. [CrossRef]

11. Xie, Z.; Fan, B.; Chen, C.; Chen, Z. An important role of an inducible rna-dependent rna polymerase in plant antiviral defense. Proc. Natl. Acad. Sci. USA 2001, 98, 6516-6521. [CrossRef]

12. Levy, M.; Edelbaum, O.; Sela, I. Tobacco mosaic virus regulates the expression of its own resistance gene n. Plant Physiol. 2004, 135, 2392-2397. [CrossRef] [PubMed]

13. Burgyan, J.; Havelda, Z. Viral suppressors of rna silencing. Trends Plant. Sci. 2011, 16, 265-272. [CrossRef] [PubMed]

14. De Ronde, D.; Butterbach, P.; Kormelink, R. Dominant resistance against plant viruses. Front. Plant Sci. 2014, 5, 1-17. [CrossRef] [PubMed]

15. Li, F.; Wang, A. Rna decay is an antiviral defense in plants that is counteracted by viral rna silencing suppressors. PLoS Pathog. 2018, 14, e1007228. [CrossRef] [PubMed]

16. Cheng, X.; Wang, A. The potyvirus silencing suppressor protein vpg mediates degradation of sgs 3 via ubiquitination and autophagy pathways. J. Virol. 2017, 91. [CrossRef]

17. Pollari, M.; De, S.; Wang, A.; Mäkinen, K. The potyviral silencing suppressor hcpro recruits and employs host argonaute1 in pro-viral functions. PLoS Pathog. 2020, 16, e1008965. [CrossRef]

18. Kovalev, N.; de Castro, I.F.; Pogany, J.; Barajas, D.; Pathak, K.; Risco, C.; Nagy, P.D. Role of viral rna and co-opted cellular escrt-i and escrt-iii factors in formation of tombusvirus spherules harboring the tombusvirus replicase. J. Virol. 2016, 90, 3611-3626. [CrossRef]

19. Hwang, Y.T.; McCartney, A.W.; Gidda, S.K.; Mullen, R.T. Localization of the carnation italian ringspot virus replication protein p36 to the mitochondrial outer membrane is mediated by an internal targeting signal and the tom complex. BMC Cell Biol. 2008, 9, 54. [CrossRef] [PubMed]

20. Dufresne, P.J.; Thivierge, K.; Cotton, S.; Beauchemin, C.; Ide, C.; Ubalijoro, E.; Laliberte, J.F.; Fortin, M.G. Heat shock 70 protein interaction with turnip mosaic virus rna-dependent rna polymerase within virus-induced membrane vesicles. Virology 2008, 374, 217-227. [CrossRef] [PubMed]

21. Mine, A.; Hyodo, K.; Tajima, Y.; Kusumanegara, K.; Taniguchi, T.; Kaido, M.; Mise, K.; Taniguchi, H.; Okuno, T. Differential roles of hsp70 and hsp90 in the assembly of the replicase complex of a positive-strand rna plant virus. J. Virol. 2012, 86, 12091-12104. [CrossRef] [PubMed]

22. Zhou, Y.; Rojas, M.R.; Park, M.R.; Seo, Y.S.; Lucas, W.J.; Gilbertson, R.L. Histone h3 interacts and colocalizes with the nuclear shuttle protein and the movement protein of a geminivirus. J. Virol. 2011, 85, 11821-11832. [CrossRef] [PubMed]

23. Chou, Y.-L.; Hung, Y.-J.; Tseng, Y.-H.; Hsu, H.-T.; Yang, J.-Y.; Wung, C.-H.; Lin, N.-S.; Meng, M.; Hsu, Y.-H.; Chang, B.-Y. The stable association of virion with the triple-gene-block protein 3-based complex of bamboo mosaic virus. PLoS Pathog. 2013, 9, e1003405. [CrossRef]

24. Okinaka, Y.; Mise, K.; Suzuki, E.; Okuno, T.; Furusawa, I. The c terminus of brome mosaic virus coat protein controls viral cell-to-cell and long-distance movement. J. Virol. 2001, 75, 5385-5390. [CrossRef]

25. Dalmay, T.; Rubino, L.; Burgyan, J.; Kollar, A.; Russo, M. Functional analysis of cymbidium ringspot virus genome. Virology 1993, 194, 697-704. [CrossRef]

26. Xiang, Y.; Kakani, K.; Reade, R.; Hui, E.; Rochon, D. A 38-amino-acid sequence encompassing the arm domain of the cucumber necrosis virus coat protein functions as a chloroplast transit peptide in infected plants. J. Virol. 2006, 80, 7952-7964. [CrossRef]

27. Kim, S.H.; Macfarlane, S.; Kalinina, N.O.; Rakitina, D.V.; Ryabov, E.V.; Gillespie, T.; Haupt, S.; Brown, J.W.; Taliansky, M. Interaction of a plant virus-encoded protein with the major nucleolar protein fibrillarin is required for systemic virus infection. Proc. Natl. Acad. Sci. USA 2007, 104, 11115-11120. [CrossRef]

28. Movahed, N.; Sun, J.; Vali, H.; Laliberte, J.F.; Zheng, H. A host er fusogen is recruited by turnip mosaic virus for maturation of viral replication vesicles. Plant Physiol. 2019, 179, 507-518. [CrossRef]

29. Mathioudakis, M.M.; Khechmar, S.; Owen, C.A.; Medina, V.; Ben Mansour, K.; Tomaszewska, W.; Spanos, T.; Sarris, P.F.; Livieratos, I.C. A thioredoxin domain-containing protein interacts with pepino mosaic virus triple gene block protein 1. Int. J. Mol. Sci. 2018, 19, 3747. [CrossRef] [PubMed]

30. Verchot-Lubicz, J.; Torrance, L.; Solovyev, A.G.; Morozov, S.Y.; Jackson, A.O.; Gilmer, D. Varied movement strategies employed by triple gene block-encoding viruses. Mol. Plant Microbe Interact. 2010, 23, 1231-1247. [CrossRef] 
31. Turner, K.A.; Sit, T.L.; Callaway, A.S.; Allen, N.S.; Lommel, S.A. Red clover necrotic mosaic virus replication proteins accumulate at the endoplasmic reticulum. Virology 2004, 320, 276-290. [CrossRef] [PubMed]

32. Kusumanegara, K.; Mine, A.; Hyodo, K.; Kaido, M.; Mise, K.; Okuno, T. Identification of domains in p27 auxiliary replicase protein essential for its association with the endoplasmic reticulum membranes in red clover necrotic mosaic virus. Virology 2012, 433, 131-141. [CrossRef]

33. Kaido, M.; Tsuno, Y.; Mise, K.; Okuno, T. Endoplasmic reticulum targeting of the red clover necrotic mosaic virus movement protein is associated with the replication of viral rna1 but not that of rna2. Virology 2009, 395, 232-242. [CrossRef] [PubMed]

34. Levy, A.; Zheng, J.Y.; Lazarowitz, S.G. Synaptotagmin syta forms er-plasma membrane junctions that are recruited to plasmodesmata for plant virus movement. Curr. Biol. 2015, 25, 2018-2025. [CrossRef]

35. McCartney, A.W.; Greenwood, J.S.; Fabian, M.R.; White, K.A.; Mullen, R.T. Localization of the tomato bushy stunt virus replication protein $\mathrm{p} 33$ reveals a peroxisome-to-endoplasmic reticulum sorting pathway. Plant Cell 2005, 17, 3513-3531. [CrossRef]

36. Scholthof, H.B.; Scholthof, K.B.; Kikkert, M.; Jackson, A.O. Tomato bushy stunt virus spread is regulated by two nested genes that function in cell-to-cell movement and host-dependent systemic invasion. Virology 1995, 213, 425-438. [CrossRef] [PubMed]

37. Kawakami, S.; Watanabe, Y.; Beachy, R.N. Tobacco mosaic virus infection spreads cell to cell as intact replication complexes. Proc. Natl. Acad. Sci. USA 2004, 101, 6291-6296. [CrossRef] [PubMed]

38. Zhang, C.; Liu, Y.; Sun, X.; Qian, W.; Zhang, D.; Qiu, B. Characterization of a specific interaction between ip-1, a tobacco protein localized in the thylakoid membranes, and tomato mosaic virus coat protein. Biochem. Biophys. Res. Commun. 2008, 374, 253-257. [CrossRef] [PubMed]

39. Geng, C.; Yan, Z.Y.; Cheng, D.J.; Liu, J.; Tian, Y.P.; Zhu, C.X.; Wang, H.Y.; Li, X.D. Tobacco vein banding mosaic virus $6 \mathrm{k} 2$ protein hijacks nbpsbo1 for virus replication. Sci. Rep. 2017, 7, 43455. [CrossRef]

40. Geng, C.; Cong, Q.Q.; Li, X.D.; Mou, A.L.; Gao, R.; Liu, J.L.; Tian, Y.P. Developmentally regulated plasma membrane protein of nicotiana benthamiana contributes to potyvirus movement and transports to plasmodesmata via the early secretory pathway and the actomyosin system. Plant Physiol. 2015, 167, 394-410. [CrossRef]

41. Hiraguri, A.; Netsu, O.; Sasaki, N.; Nyunoya, H.; Sasaya, T. Recent progress in research on cell-to-cell movement of rice viruses. Front. Microbiol. 2014, 5, 210. [CrossRef] [PubMed]

42. Yuan, Z.; Chen, H.; Chen, Q.; Omura, T.; Xie, L.; Wu, Z.; Wei, T. The early secretory pathway and an actin-myosin viii motility system are required for plasmodesmatal localization of the nsvc4 protein of rice stripe virus. Virus Res. 2011, 159, 62-68. [CrossRef] [PubMed]

43. Cho, W.K.; Lian, S.; Kim, S.M.; Park, S.H.; Kim, K.H. Current insights into research on rice stripe virus. Plant Pathol. J. 2013, 29 , 223-233. [CrossRef] [PubMed]

44. Harries, P.A.; Palanichelvam, K.; Yu, W.C.; Schoelz, J.E.; Nelson, R.S. The cauliflower mosaic virus protein p6 forms motile inclusions that traffic along actin microfilaments and stabilize microtubules. Plant Physiol. 2009, 149, 1005-1016. [CrossRef]

45. Thiébeauld, O.; Schepetilnikov, M.; Park, H.-S.; Geldreich, A.; Kobayashi, K.; Keller, M.; Hohn, T.; Ryabova, L.A. A new plant protein interacts with eif3 and 60s to enhance virus-activated translation re-initiation. EMBO J. 2009, 28, 3171-3184. [CrossRef]

46. Huang, Y.W.; Hu, C.C.; Liou, M.R.; Chang, B.Y.; Tsai, C.H.; Meng, M.; Lin, N.S.; Hsu, Y.H. Hsp90 interacts specifically with viral rna and differentially regulates replication initiation of bamboo mosaic virus and associated satellite rna. PLoS Pathog. 2012, 8, e1002726. [CrossRef]

47. Chen, I.H.; Chiu, M.H.; Cheng, S.F.; Hsu, Y.H.; Tsai, C.H. The glutathione transferase of nicotiana benthamiana nbgstu4 plays a role in regulating the early replication of bamboo mosaic virus. New Phytol. 2013, 199, 749-757. [CrossRef]

48. Diaz, A.; Zhang, J.; Ollwerther, A.; Wang, X.; Ahlquist, P. Host escrt proteins are required for bromovirus rna replication compartment assembly and function. PLoS Pathog. 2015, 11, e1004742. [CrossRef] [PubMed]

49. Jungfleisch, J.; Chowdhury, A.; Alves-Rodrigues, I.; Tharun, S.; Diez, J. The lsm1-7-pat1 complex promotes viral rna translation and replication by differential mechanisms. RNA 2015, 21, 1469-1479. [CrossRef] [PubMed]

50. Diez, J.; Ishikawa, M.; Kaido, M.; Ahlquist, P. Identification and characterization of a host protein required for efficient template selection in viral rna replication. Proc. Natl. Acad. Sci. USA 2000, 97, 3913-3918. [CrossRef]

51. Richardson, L.G.; Clendening, E.A.; Sheen, H.; Gidda, S.K.; White, K.A.; Mullen, R.T. A unique n-terminal sequence in the carnation italian ringspot virus p36 replicase-associated protein interacts with the host cell escrt-i component vps23. J. Virol. 2014, 88, 6329-6344. [CrossRef]

52. Barajas, D.; Xu, K.; de Castro Martin, I.F.; Sasvari, Z.; Brandizzi, F.; Risco, C.; Nagy, P.D. Co-opted oxysterol-binding orp and vap proteins channel sterols to rna virus replication sites via membrane contact sites. PLoS Pathog. 2014, 10, e1004388. [CrossRef]

53. Mathioudakis, M.; Rita, S.L.V.; Canto, T.; Medina, V.; Mossialos, D.; Makris Antonios, M.; Livieratos, I. Pepino mosaic virus triple gene block protein 1 (tgbp1) interacts with and increases tomato catalase 1 activity to enhance virus accumulation. Mol. Plant Pathol. 2013, 14, 589-601. [CrossRef] [PubMed]

54. Fridborg, I.; Grainger, J.; Page, A.; Coleman, M.; Findlay, K.; Angell, S. Tip, a novel host factor linking callose degradation with the cell-to-cell movement of potato virus x. Mol. Plant Microbe Interact. 2003, 16, 132-140. [CrossRef]

55. Hyodo, K.; Suzuki, N.; Okuno, T. Hijacking a host scaffold protein, rack1, for replication of a plant rna virus. New Phytol. 2019, 221, 935-945. [CrossRef] [PubMed]

56. Li, J.; Xiang, C.Y.; Yang, J.; Chen, J.P.; Zhang, H.M. Interaction of hsp20 with a viral rdrp changes its sub-cellular localization and distribution pattern in plants. Sci. Rep. 2015, 5, 14016. [CrossRef] 
57. Li, Z.; Pogany, J.; Tupman, S.; Esposito, A.M.; Kinzy, T.G.; Nagy, P.D. Translation elongation factor 1a facilitates the assembly of the tombusvirus replicase and stimulates minus-strand synthesis. PLoS Pathog. 2010, 6, e1001175. [CrossRef] [PubMed]

58. Barajas, D.; Jiang, Y.; Nagy, P.D. A unique role for the host escrt proteins in replication of tomato bushy stunt virus. PLoS Pathog. 2009, 5, e1000705. [CrossRef] [PubMed]

59. Wang, R.Y.; Nagy, P.D. Tomato bushy stunt virus co-opts the rna-binding function of a host metabolic enzyme for viral genomic rna synthesis. Cell Host Microbe 2008, 3, 178-187. [CrossRef]

60. Pogany, J.; Stork, J.; Li, Z.; Nagy, P.D. In vitro assembly of the tomato bushy stunt virus replicase requires the host heat shock protein 70. Proc. Natl. Acad. Sci. USA 2008, 105, 19956-19961. [CrossRef]

61. Wang, R.Y.-L.; Stork, J.; Nagy, P.D. A key role for heat shock protein 70 in the localization and insertion of tombusvirus replication proteins to intracellular membranes. J. Virol. 2009, 83, 3276-3287. [CrossRef] [PubMed]

62. Yamaji, Y.; Kobayashi, T.; Hamada, K.; Sakurai, K.; Yoshii, A.; Suzuki, M.; Namba, S.; Hibi, T. In vivo interaction between tobacco mosaic virus rna-dependent rna polymerase and host translation elongation factor 1a. Virology 2006, 347, 100-108. [CrossRef]

63. Huang, T.S.; Wei, T.; Laliberte, J.; Wang, A. A host rna helicase-like protein, atrh8, interacts with the potyviral genome-linked protein, vpg, associates with the virus accumulation complex, and is essential for infection. Plant Physiol. 2010, 152, 255-266. [CrossRef]

64. Li, Y.; Xiong, R.; Bernards, M.; Wang, A. Recruitment of arabidopsis rna helicase atrh9 to the viral replication complex by viral replicase to promote turnip mosaic virus replication. Sci. Rep. 2016, 6, 30297. [CrossRef]

65. Thivierge, K.; Cotton, S.; Dufresne, P.J.; Mathieu, I.; Beauchemin, C.; Ide, C.; Fortin, M.G.; Laliberte, J.F. Eukaryotic elongation factor 1a interacts with turnip mosaic virus rna-dependent rna polymerase and vpg-pro in virus-induced vesicles. Virology 2008, 377, 216-225. [CrossRef] [PubMed]

66. Beauchemin, C.; Laliberte, J.F. The poly(a) binding protein is internalized in virus-induced vesicles or redistributed to the nucleolus during turnip mosaic virus infection. J. Virol. 2007, 81, 10905-10913. [CrossRef] [PubMed]

67. Nishikiori, M.; Dohi, K.; Mori, M.; Meshi, T.; Naito, S.; Ishikawa, M. Membrane-bound tomato mosaic virus replication proteins participate in rna synthesis and are associated with host proteins in a pattern distinct from those that are not membrane bound. J. Virol. 2006, 80, 8459-8468. [CrossRef]

68. Gorovits, R.; Moshe, A.; Ghanim, M.; Czosnek, H. Recruitment of the host plant heat shock protein 70 by tomato yellow leaf curl virus coat protein is required for virus infection. PLoS ONE 2013, 8, e70280. [CrossRef]

69. Xu, K.; Nagy, P.D. Enrichment of phosphatidylethanolamine in viral replication compartments via co-opting the endosomal rab5 small gtpase by a positive-strand rna virus. PLoS Biol. 2016, 14, e2000128. [CrossRef]

70. Diaz, A.; Wang, X.; Ahlquist, P. Membrane-shaping host reticulon proteins play crucial roles in viral rna replication compartment formation and function. Proc. Natl. Acad. Sci. USA 2010, 107, 16291-16296. [CrossRef]

71. Wei, T.; Zhang, C.; Hou, X.; Sanfaçon, H.; Wang, A. The snare protein syp71 is essential for turnip mosaic virus infection by mediating fusion of virus-induced vesicles with chloroplasts. PLoS Pathog. 2013, 9, e1003378. [CrossRef] [PubMed]

72. Huang, Y.P.; Jhuo, J.H.; Tsai, M.S.; Tsai, C.H.; Chen, H.C.; Lin, N.S.; Hsu, Y.H.; Cheng, C.P. Nbrabg3f, a member of rab gtpase, is involved in bamboo mosaic virus infection in nicotiana benthamiana. Mol. Plant Pathol. 2016, 17, 714-726. [CrossRef] [PubMed]

73. Carluccio, A.V.; Zicca, S.; Stavolone, L. Hitching a ride on vesicles: Cauliflower mosaic virus movement protein trafficking in the endomembrane system. Plant Physiol. 2014, 164, 1261. [CrossRef]

74. Hyodo, K.; Mine, A.; Taniguchi, T.; Kaido, M.; Mise, K.; Taniguchi, H.; Okuno, T. Adp ribosylation factor 1 plays an essential role in the replication of a plant rna virus. J. Virol. 2013, 87, 163-176. [CrossRef] [PubMed]

75. Rodriguez, A.; Angel, C.A.; Lutz, L.; Leisner, S.M.; Nelson, R.S.; Schoelz, J.E. Association of the p6 protein of cauliflower mosaic virus with plasmodesmata and plasmodesmal proteins. Plant Physiol. 2014, 166, 1345-1358. [CrossRef]

76. Hyodo, K.; Hashimoto, K.; Kuchitsu, K.; Suzuki, N.; Okuno, T. Harnessing host ros-generating machinery for the robust genome replication of a plant rna virus. Proc. Natl. Acad. Sci. USA 2017, 114, E1282-E1290. [CrossRef]

77. Vijayapalani, P.; Maeshima, M.; Nagasaki-Takekuchi, N.; Miller, W.A. Interaction of the trans-frame potyvirus protein p3n-pipo with host protein pcap1 facilitates potyvirus movement. PLoS Pathog. 2012, 8, e1002639. [CrossRef]

78. Yoshii, A.; Shimizu, T.; Yoshida, A.; Hamada, K.; Sakurai, K.; Yamaji, Y.; Suzuki, M.; Namba, S.; Hibi, T. Nth201, a novel class ii knotted1-like protein, facilitates the cell-to-cell movement of tobacco mosaic virus in tobacco. Mol. Plant Microbe Interact. 2008, 21, 586-596. [CrossRef]

79. Uhrig, J.F.; Canto, T.; Marshall, D.; MacFarlane, S.A. Relocalization of nuclear aly proteins to the cytoplasm by the tomato bushy stunt virus p19 pathogenicity protein. Plant Physiol. 2004, 135, 2411-2423. [CrossRef]

80. Hagiwara-Komoda, Y.; Hirai, K.; Mochizuki, A.; Nishiguchi, M.; Meshi, T.; Ishikawa, M. Overexpression of a host factor tom1 inhibits tomato mosaic virus propagation and suppression of rna silencing. Virology 2008, 376, 132-139. [CrossRef]

81. Yamanaka, T.; Imai, T.; Satoh, R.; Kawashima, A.; Takahashi, M.; Tomita, K.; Kubota, K.; Meshi, T.; Naito, S.; Ishikawa, M. Complete inhibition of tobamovirus multiplication by simultaneous mutations in two homologous host genes. J. Virol. 2002, 76, 2491-2497. [CrossRef]

82. Hafren, A.; Macia, J.L.; Love, A.J.; Milner, J.J.; Drucker, M.; Hofius, D. Selective autophagy limits cauliflower mosaic virus infection by nbr1-mediated targeting of viral capsid protein and particles. Proc. Natl. Acad. Sci. USA 2017, 114, E2026-E2035. [CrossRef] 
83. Ballut, L.; Drucker, M.; Pugniere, M.; Cambon, F.; Blanc, S.; Roquet, F.; Candresse, T.; Schmid, H.P.; Nicolas, P.; Gall, O.L.; et al. Hcpro, a multifunctional protein encoded by a plant rna virus, targets the 20s proteasome and affects its enzymic activities. J. Gen. Virol. 2005, 86, 2595-2603. [CrossRef]

84. Dielen, A.S.; Sassaki, F.T.; Walter, J.; Michon, T.; Menard, G.; Pagny, G.; Krause-Sakate, R.; Ide, G.M.; Badaoui, S.; Le Gall, O.; et al. The 20s proteasome alpha5 subunit of arabidopsis thaliana carries an rnase activity and interacts in planta with the lettuce mosaic potyvirus hcpro protein. Mol. Plant Pathol. 2011, 12, 137-150. [CrossRef]

85. Cho, S.Y.; Cho, W.K.; Choi, H.S.; Kim, K.H. Cis-acting element (sl1) of potato virus x controls viral movement by interacting with the nbmpb2cb and viral proteins. Virology 2012, 427, 166-176. [CrossRef]

86. Wu, C.Y.; Nagy, P.D. Blocking tombusvirus replication through the antiviral functions of ddx17-like rh30 dead-box helicase. PLoS Pathog. 2019, 15, e1007771. [CrossRef] [PubMed]

87. Hafren, A.; Ustun, S.; Hochmuth, A.; Svenning, S.; Johansen, T.; Hofius, D. Turnip mosaic virus counteracts selective autophagy of the viral silencing suppressor hcpro. Plant Physiol. 2018, 176, 649-662. [CrossRef] [PubMed]

88. Baltazar, B.M.; Espinoza, L.C.; Banda, A.E.; de la Fuente Martinez, J.M.; Tiznado, J.A.G.; Garcia, J.G.; Gutierrez, M.A.; Rodriguez, J.L.G.; Diaz, O.H.; Horak, M.J.; et al. Pollen-mediated gene flow in maize: Implications for isolation requirements and coexistence in mexico, the center of origin of maize. PLoS ONE 2015, 10, e0131549. [CrossRef]

89. Timperio, A.; Egidi, M.; Zolla, L. Proteomics applied on plant abiotic stresses: Role of heat shock proteins (hsp). Elsevier 2008, 71, 391-411. [CrossRef] [PubMed]

90. Huang, Y.P.; Chen, I.H.; Tsai, C.H. Host factors in the infection cycle of bamboo mosaic virus. Front. Microbiol. 2017, 8, 437. [CrossRef] [PubMed]

91. Wollert, T.; Hurley, J. Molecular mechanism of multivesicular body biogenesis by escrt complexes. Nature 2010, 464, 864-869. [CrossRef]

92. Contreras-Paredes, C.A.; Silva-Rosales, L.; Daros, J.A.; Alejandri-Ramirez, N.D.; Dinkova, T.D. The absence of eukaryotic initiation factor eif(iso) $4 \mathrm{e}$ affects the systemic spread of a tobacco etch virus isolate in arabidopsis thaliana. Mol. Plant Microbe Interact. 2013, 26, 461-470. [CrossRef]

93. Morris, D.R.; Geballe, A.P. Upstream open reading frames as regulators of mrna translation. Mol. Cell. Biol. 2000, 20, 8635-8642. [CrossRef]

94. Cordin, O.; Banroques, J.; Tanner, N.K.; Linder, P. The dead-box protein family of rna helicases. Gene 2006, 367, 17-37. [CrossRef]

95. Kim, J.S.; Kim, K.A.; Oh, R.T.; Park, C.M.; Kang, H. Functional characterization of dead-box rna helicases in arabidopsis thaliana under abiotic stress conditions. Plant. Cell Physiol. 2008, 49, 1563-1571. [CrossRef] [PubMed]

96. Noueiry, A.O.; Chen, J.; Ahlquist, P. A mutant allele of essential, general translation initiation factor ded1 selectively inhibits translation of a viral mrna. Proc. Natl. Acad. Sci. USA 2000, 97, 12985-12990. [CrossRef] [PubMed]

97. Jiang, Y.; Serviene, E.; Gal, J.; Panavas, T.; Nagy, P.D. Identification of essential host factors affecting tombusvirus rna replication based on the yeast tet promoters hughes collection. J. Virol. 2006, 80, 7394-7404. [CrossRef] [PubMed]

98. Prasanth, K.R.; Huang, Y.W.; Liou, M.R.; Wang, R.Y.; Hu, C.C.; Tsai, C.H.; Meng, M.; Lin, N.S.; Hsu, Y.H. Glyceraldehyde 3-phosphate dehydrogenase negatively regulates the replication of bamboo mosaic virus and its associated satellite rna. J. Virol. 2011, 85, 8829-8840. [CrossRef]

99. Dixon, D.; Lapthorn, A.; Edwards, R. Protein family review: Plant glutathione transferases. Genome Biol. 2002, 3, 1-10. [CrossRef] [PubMed]

100. Skopelitou, K.; Muleta, A.W.; Papageorgiou, A.C.; Chronopoulou, E.; Labrou, N.E. Catalytic features and crystal structure of a tau class glutathione transferase from glycine max specifically upregulated in response to soybean mosaic virus infections. Biochim. Biophys. Acta 2015, 1854, 166-177. [CrossRef] [PubMed]

101. Weber-Boyvat, M.; Zhong, W.; Yan, D.; Olkkonen, V.M. Oxysterol-binding proteins: Functions in cell regulation beyond lipid metabolism. Biochem. Pharmacol. 2013, 86, 89-95. [CrossRef]

102. Islas-Flores, T.; Rahman, A.; Ullah, H.; Villanueva, M.A. The receptor for activated c kinase in plant signaling: Tale of a promiscuous little molecule. Front. Plant Sci. 2015, 6, 1090. [CrossRef]

103. Nakashima, A.; Chen, L.; Thao, N.P.; Fujiwara, M.; Wong, H.L.; Kuwano, M.; Umemura, K.; Shirasu, K.; Kawasaki, T.; Shimamoto, K. Rack1 functions in rice innate immunity by interacting with the rac1 immune complex. Plant Cell 2008, 20, 2265-2279. [CrossRef] [PubMed]

104. Cheng, Z.; Li, J.F.; Niu, Y.; Zhang, X.C.; Woody, O.Z.; Xiong, Y.; Djonovic, S.; Millet, Y.; Bush, J.; McConkey, B.J.; et al. Pathogensecreted proteases activate a novel plant immune pathway. Nature 2015, 521, 213-216. [CrossRef] [PubMed]

105. Adams, D.R.; Ron, D.; Kiely, P.A. Rack1, a multifaceted scaffolding protein: Structure and function. Cell Commun. Signal. 2011, 9, 22. [CrossRef]

106. Otegui, M.S.; Spitzer, C. Endosomal functions in plants. Traffic 2008, 9, 1589-1598. [CrossRef]

107. Lundquist, E. Small GTPases. WormBook 2006, 1-18. [CrossRef] [PubMed]

108. Romero-Brey, I.; Bartenschlager, R. Endoplasmic reticulum: The favorite intracellular niche for viral replication and assembly. Viruses 2016, 8, 160. [CrossRef] [PubMed]

109. Sanderfoot, A.; Kovaleva, V.; Bassham, D.; Raikhel, N. Interactions between syntaxins identify at least five snare complexes within the golgi/prevacuolar system of the arabidopsis cell. Mol. Biol. Cell 2001, 12, 3733-3743. [CrossRef] 
110. Suwastika, N.; Uemura, T.; Shiina, T.; Sato, M.; Takeyasu, K. Suwastika in, uemura t, shiina t, sato mh, takeyasu. Cell Struct. Funct. 2008, 33, 185-192. [CrossRef]

111. Nziengui, H.; Schoefs, B. Functions of reticulons in plants: What we can learn from animals and yeasts. Cell Mol. Life Sci. 2009, 66, 584-595. [CrossRef] [PubMed]

112. Chen, J.; Stefano, G.; Brandizzi, F.; Zheng, H. Arabidopsis rhd3 mediates the generation of the tubular er network and is required for golgi distribution and motility in plant cells. J. Cell Sci. 2011, 124, 2241-2252. [CrossRef]

113. Cheng, S.-F.; Huang, Y.-P.; Wu, Z.-R.; Hu, C.-C.; Hsu, Y.-H.; Tsai, C.-H. Identification of differentially expressed genes induced by bamboo mosaic virus infection in nicotiana benthamianaby cdna-amplified fragment length polymorphism. BMC Plant Biol. 2010, 10, 286. [CrossRef] [PubMed]

114. Memon, A.R. The role of adp-ribosylation factor and sar1 in vesicular trafficking in plants. Biochim. Biophys. Acta 2004, 1664, 9-30. [CrossRef]

115. Harries, P.; Ding, B. Cellular factors in plant virus movement: At the leading edge of macromolecular trafficking in plants. Virology 2011, 411, 237-243. [CrossRef] [PubMed]

116. Suzuki, N.; Miller, G.; Morales, J.; Shulaev, V.; Torres, M.A.; Mittler, R. Respiratory burst oxidases: The engines of ros signaling. Curr. Opin. Plant Biol. 2011, 14, 691-699. [CrossRef]

117. Deng, X.G.; Zhu, T.; Zou, L.J.; Han, X.Y.; Zhou, X.; Xi, D.H.; Zhang, D.W.; Lin, H.H. Orchestration of hydrogen peroxide and nitric oxide in brassinosteroid-mediated systemic virus resistance in nicotiana benthamiana. Plant J. 2016, 85, 478-493. [CrossRef]

118. Deng, X.-G.; Zhu, T.; Peng, X.-J.; Xi, D.-H.; Guo, H.; Yin, Y.; Zhang, D.-W.; Lin, H.-H. Role of brassinosteroid signaling in modulating tobacco mosaic virus resistance in nicotiana benthamiana. Sci. Rep. 2016, 6, 20579. [CrossRef] [PubMed]

119. Pfaff, C.; Ehrnsberger, H.; Flores-Tornero, M.; Sorensen, B.; Schubert, T.; Längst, G.; Griesenbeck, L.; Sprunck, S.; Grasser, M.; Grasser, K.D. Aly rna-binding proteins are required for nucleocytosolic mrna transport and modulate plant growth and development. Plant Physiol. 2018, 177, 2226-2240. [CrossRef]

120. Canto, T.; Uhrig, J.F.; Swanson, M.; Wright, K.M.; MacFarlane, S.A. Translocation of tomato bushy stunt virus p19 protein into the nucleus by aly proteins compromises its silencing suppressor activity. J. Virol. 2006, 80, 9064-9072. [CrossRef] [PubMed]

121. Clavel, M.; Michaeli, S.; Genschik, P. Autophagy: A double-edged sword to fight plant viruses. Trends Plant Sci. 2017, 22, 646-648. [CrossRef] [PubMed]

122. Haxim, Y.; Ismayil, A.; Jia, Q.; Wang, Y.; Zheng, X.; Chen, T.; Qian, L.; Liu, N.; Wang, Y.; Han, S.; et al. Autophagy functions as an antiviral mechanism against geminiviruses in plants. eLife 2017, 6, e23897. [CrossRef] [PubMed]

123. Hafren, A.; Lohmus, A.; Makinen, K. Formation of potato virus a-induced rna granules and viral translation are interrelated processes required for optimal virus accumulation. PLoS Pathog. 2015, 11, e1005314. [CrossRef]

124. Pitzalis, N.; Amari, K.; Graindorge, S.; Pflieger, D.; Donaire, L.; Wassenegger, M.; Llave, C.; Heinlein, M. Turnip mosaic virus in oilseed rape activates networks of srna-mediated interactions between viral and host genomes. Commun. Biol. $2020,3,702$. [CrossRef]

125. Beauchemin, C.; Boutet, N.; Laliberte, J.F. Visualization of the interaction between the precursors of vpg, the viral protein linked to the genome of turnip mosaic virus, and the translation eukaryotic initiation factor iso 4e in planta. J. Virol. 2007, 81, 775-782. [CrossRef] [PubMed]

126. Nigam, D.; LaTourrette, K.; Souza, P.F.N.; Garcia-Ruiz, H. Genome-wide variation in potyviruses. Front. Plant Sci. 2019, 10, 1439. [CrossRef]

127. Charron, C.; Nicolaï, M.; Gallois, J.L.; Robaglia, C.; Moury, B.; Palloix, A.; Caranta, C. Natural variation and functional analyses provide evidence for co-evolution between plant eif4e and potyviral vpg. Plant J. 2008, 54, 56-68. [CrossRef]

128. Ahlquist, P.; Noueiry, A.O.; Lee, W.M.; Kushner, D.B.; Dye, B.T. Host factors in positive-strand rna virus genome replication. J. Virol. 2003, 77, 8181-8186. [CrossRef]

129. Panavas, T.; Serviene, E.; Brasher, J.; Nagy, P.D. Yeast genome-wide screen reveals dissimilar sets of host genes affecting replication of rna viruses. Proc. Natl. Acad. Sci. USA 2005, 102, 7326-7331. [CrossRef] [PubMed]

130. Yoon, Y.J.; Venkatesh, J.; Lee, J.H.; Kim, J.; Lee, H.E.; Kim, D.S.; Kang, B.C. Genome editing of eif4e1 in tomato confers resistance to pepper mottle virus. Front. Plant Sci. 2020, 11, 1098. [CrossRef] [PubMed]

131. Mahuku, G.; Lockhart, B.E.; Wanjala, B.; Jones, M.W.; Kimunye, J.N.; Stewart, L.R.; Cassone, B.J.; Sevgan, S.; Nyasani, J.O.; Kusia, E.; et al. Maize lethal necrosis (mln), an emerging threat to maize-based food security in sub-saharan africa. Phytopathology 2015, 105, 956-965. [CrossRef] [PubMed] 